\title{
Chemistry model for ablating carbon-phenolic material during atmospheric re-entry
}

\author{
Alexandre Martin* and Iain D. Boyd ${ }^{\dagger}$ \\ Department of Aerospace Engineering, The University of Michigan, Ann Arbor, MI, 48109, USA \\ Ioana Cozmuta $\ddagger$ and Michael J. Wright $\S$ \\ Reacting Flow Environments Branch, NASA Ames Research Center, Moffett Field, CA, 94035, USA
}

\begin{abstract}
Recent and future re-entry vehicle designs, such as the CEV, use ablative material as the main component of the heat shield of their thermal protection system. In order to properly predict the behavior of the vehicle, it is imperative to take into account the gases produced by the ablation process when modeling the reacting flow environment. In the case of charring ablators, where an inner resin is pyrolyzed at a relatively low temperature, the composition of the gas expelled in the boundary layer is complex and might lead to thermal chemical reactions that cannot be captured with simple flow chemistry models. In order to obtain better predictions, a proper gas flow chemistry model needs to be included in the CFD calculations. The present paper proposes an extensive set of reactions that are relevant to carbon-phenolic ablators, such as PICA, the ablative material that was used on the Stardust return capsule and that will be used on the entry vehicle of the Mars Science Laboratory (MSL).
\end{abstract}

\section{Nomenclature}

$\begin{array}{llll}A & \text { Pre-exponent factor } & \text { ppm } & \text { Parts per million } \\ \mathrm{B}_{g}^{\prime} & \text { Non dimensional pyrolysis gas rate } & S & \text { Non dimensional sensitivity } \\ \mathrm{B}_{c}^{\prime} & \text { Non dimensional surface ablation rate } & T & \text { Temperature } \\ k & \text { Kinetic rate } & T_{a} & \text { Activation temperature } \\ n & \text { Pre-exponent temperature power } & X & \text { Sensitive variable } \\ p & \text { Pressure } & & \end{array}$

\section{Introduction}

The Thermal Protection System (TPS) of a re-entry vehicle is one of the key components of its design. The materials used for the TPS can be classified into two main categories: ablative materials, as in the one used on Apollo missions, and non-ablative materials, such as the ceramic tiles used on the space shuttle. The former can also be divided into two sub-categories: charring (also know as pyrolyzing) and non-charring ablators. The theory behind the use of ablators is quite simple: the energy absorbed by the removal of material from the surface is not used to heat the TPS, thus keeping the vehicle at a relatively "cold" temperature. In the case of charring ablators, the ablative material is a resin which fills the pores of a carbon matrix. Although the matrix might ablate, it usually does not, thus preserving the original geometry of the aerodynamic surface during re-entry.

In order to properly model the heat rates at the surface of the vehicle, the ablating boundary condition must take into account many phenomena: surface recession, wall temperature, blowing rates, gas composition, surface chemistry, etc. However, to account for the effects of the pyrolysis gas on the vehicle, the

\footnotetext{
${ }^{*}$ Research Associate, AIAA Member

$\dagger$ Professor, Associate Fellow AIAA.

${ }_{\ddagger}$ Senior Research Scientist, ELORET Corporation, AIAA Member

$\S$ Senior Research Scientist, Associate Fellow AIAA
} 
chemistry model of the flow field must include the reactions associated with the presence of this gas. Although models have been proposed in the past, ${ }^{1,2}$ sensitivity analyses on reactions were not performed, important reactions were not included, and some of the reactions rates were inappropriate or simply outdated. The present paper tries to improve on those models by addressing these omissions. Because ablation coupling is becoming an increasingly important research topic, ${ }^{3-9}$ the development of an accurate, yet usable, chemistry model is of great importance.

The elaboration of the model is done following the methodology proposed by Ref. 10. In this regard, three models are developed. The first one, the complete model, takes into account as many chemical reactions and species as is reasonably possible, regardless of their apparent importance. The second model, the reduced model, uses sensitivity analysis to reduce the number of species and reactions, considering key parameters such as temperature and the mole fraction of important species. The third model, presented in a future communication, will further reduce the reactions and species so that it can be used efficiently in hypersonic CFD codes. ${ }^{11-14}$

\section{Complete model}

\section{A. Species selection}

Air species

Because the model is intended to be used in Earth's atmosphere, it is therefore important to include air species. In order to be thorough, ionized species are also included:

$$
\mathrm{N}_{2}, \mathrm{O}_{2}, \mathrm{NO}, \mathrm{N}, \mathrm{O}, \mathrm{N}_{2}^{+}, \mathrm{O}_{2}^{+}, \mathrm{NO}^{+}, \mathrm{N}^{+}, \mathrm{O}^{+}, \mathrm{e}^{-}
$$

\section{Ablation species}

The surface ablation and pyrolysis of carbon-phenolic material is a complex chemistry problem. In order to evaluate the chemical composition at the surface, the re-entry trajectory of the Stardust vehicle and proposed trajectories of the CEV are used. One of the assumptions is that, at the surface, the gas is at thermochemical equilibrium. The method of analysis for the thermal protection system begins with computing the flow field over a discrete set of points along the estimated flight trajectory to sufficiently capture the heat pulse. High fidelity solutions are computed at several points in the trajectory with the CFD code DPLR. ${ }^{13}$ For Stardust, these discrete solutions are interpolated (using engineering relationships) in time along the trajectory. The heat transfer coefficient, the surface pressure and the freestream enthalpy are the environment inputs calculated for each body point along the entire trajectory and used in the material code response, FIAT. ${ }^{15}$ For the CEV cases, the aerothermodynamic analysis tool CBAero ${ }^{16}$ is used to provide the same input parameters.

For the current analysis, for Stardust, only the conditions at the stagnation point are considered, without accounting for the contribution from the radiative heating $(\sim 10 \%)$. For CEV, three body points are considered with two different heating levels calculated using different margins. The FIAT version 2.4 material response code $^{15}$ is used to model PICA material response. The material properties (heat capacity, thermal

conductivity, emissivity) of the material in the TPS stack are read from the FIAT material database. The 3.3 version of the PICA $^{17}$ model is used in the present analysis; a representative composition, taken from Ref. 1, is shown in Table 2. FIAT provides quantities such as surface temperature, density profiles, recession, ablation and pyrolysis.

For selected time steps throughout the two analyzed trajectories, the pressure, $\mathrm{B}_{g}^{\prime}$ and $\mathrm{B}_{c}^{\prime}$ values predicted by FIAT are then extracted and input to the Multicomponent Ablation Thermochemistry (MAT) code. ${ }^{18}$ When given this information, MAT calculates back from the $\mathrm{B}^{\prime}$ tables the species mole fractions according to JANNAF information corresponding to the wall temperature predicted by FIAT.

From these results, trajectories points are chosen so the widest possible combination of pressure and temperature is represented. Figure 1 shows the parameter space represented by those points.

The MAT results are used to select which species are to be considered in the model; as listed in Table 1 , only the species with the highest concentrations are kept. In order to be self-consistent, the species are not chosen using a threshold value, but instead, are selected by summing their mole fraction and making sure the error is kept below $0.1 \%$. This ensures that the species chosen would be representative of the actual computed values. In order to be even more thorough, the species enthalpy could have been considered, as 
Table 1. Species mole fraction of the ablating gas for the chosen trajectory points (Stardust and CEV)

\begin{tabular}{|c|c|c|c|c|c|c|c|c|c|}
\hline \# & $\begin{array}{c}\text { Temp. } \\
{[\mathrm{K}]}\end{array}$ & $\begin{array}{c}\text { Pressure } \\
\text { [Atm.] }\end{array}$ & $\mathrm{H}_{2}$ & $\mathrm{CO}$ & $\mathrm{N}_{2}$ & $\mathrm{CH}_{4}$ & $\mathrm{H}_{2} \mathrm{O}$ & $\mathrm{CO}_{2}$ & $\mathrm{OH}$ \\
\hline 1 & 750.0 & 0.00014 & $3.60 \mathrm{E}-1$ & $3.08 \mathrm{E}-1$ & $2.49 \mathrm{E}-1$ & $8.28 \mathrm{E}-2$ & & & \\
\hline 2 & 750.0 & 0.00041 & $3.81 \mathrm{E}-1$ & $3.01 \mathrm{E}-1$ & $2.83 \mathrm{E}-1$ & $3.53 \mathrm{E}-2$ & & & \\
\hline 3 & 813.8 & 0.02400 & $2.73 \mathrm{E}-2$ & $2.19 \mathrm{E}-1$ & $6.77 \mathrm{E}-1$ & & $2.28 \mathrm{E}-3$ & $7.45 \mathrm{E}-2$ & \\
\hline 4 & 859.8 & 0.08732 & $6.70 \mathrm{E}-2$ & $2.18 \mathrm{E}-1$ & $6.38 \mathrm{E}-1$ & & $6.96 \mathrm{E}-3$ & $6.94 \mathrm{E}-2$ & \\
\hline 5 & 892.4 & 0.11167 & $3.69 \mathrm{E}-2$ & $2.56 \mathrm{E}-1$ & $6.53 \mathrm{E}-1$ & & $2.89 \mathrm{E}-3$ & $5.08 \mathrm{E}-2$ & \\
\hline 6 & 1500 & 0.00327 & $4.85 \mathrm{E}-1$ & $2.76 \mathrm{E}-1$ & $1.57 \mathrm{E}-1$ & & & & \\
\hline 7 & 1750 & 0.288 & & & $7.67 \mathrm{E}-1$ & & $3.96 \mathrm{E}-2$ & $2.96 \mathrm{E}-2$ & \\
\hline 8 & 2000 & 0.14693 & & $5.12 \mathrm{E}-4$ & $7.49 \mathrm{E}-1$ & & $6.94 \mathrm{E}-2$ & $5.22 \mathrm{E}-2$ & $2.44 \mathrm{E}-3$ \\
\hline 9 & 2250 & 0.03136 & $2.98 \mathrm{E}-1$ & $2.53 \mathrm{E}-1$ & $3.88 \mathrm{E}-1$ & & $5.29 \mathrm{E}-2$ & $8.36 \mathrm{E}-3$ & $6.21 \mathrm{E}-4$ \\
\hline 10 & 2250 & 0.04711 & $2.35 \mathrm{E}-1$ & $2.24 \mathrm{E}-1$ & $4.40 \mathrm{E}-1$ & & $8.57 \mathrm{E}-2$ & $1.52 \mathrm{E}-2$ & $9.23 \mathrm{E}-4$ \\
\hline 11 & 2250 & 0.23807 & $3.90 \mathrm{E}-4$ & $1.59 \mathrm{E}-3$ & $7.55 \mathrm{E}-1$ & & $4.63 \mathrm{E}-2$ & $3.52 \mathrm{E}-2$ & $5.44 \mathrm{E}-3$ \\
\hline 12 & 2750 & 0.01849 & $2.41 \mathrm{E}-1$ & $2.23 \mathrm{E}-1$ & $4.34 \mathrm{E}-1$ & & $6.20 \mathrm{E}-2$ & $8.52 \mathrm{E}-3$ & $1.73 \mathrm{E}-2$ \\
\hline 13 & 2750 & 0.13282 & $5.78 \mathrm{E}-2$ & $1.12 \mathrm{E}-1$ & $6.02 \mathrm{E}-1$ & & $1.30 \mathrm{E}-1$ & $3.74 \mathrm{E}-2$ & $2.76 \mathrm{E}-2$ \\
\hline 14 & 3042 & 0.19887 & $4.74 \mathrm{E}-2$ & $9.14 \mathrm{E}-2$ & $6.20 \mathrm{E}-1$ & & $8.22 \mathrm{E}-2$ & $2.18 \mathrm{E}-2$ & $4.52 \mathrm{E}-2$ \\
\hline 15 & 3211 & 0.2303 & $5.13 \mathrm{E}-2$ & $8.16 \mathrm{E}-2$ & $6.15 \mathrm{E}-1$ & & $4.43 \mathrm{E}-2$ & $9.16 \mathrm{E}-3$ & $5.29 \mathrm{E}-2$ \\
\hline 16 & 3220 & 0.367 & $3.07 \mathrm{E}-2$ & $6.12 \mathrm{E}-2$ & $6.44 \mathrm{E}-1$ & & $4.08 \mathrm{E}-2$ & $1.06 \mathrm{E}-2$ & $4.99 \mathrm{E}-2$ \\
\hline 17 & 3307 & 0.196 & $3.79 \mathrm{E}-2$ & $2.90 \mathrm{E}-1$ & $4.24 \mathrm{E}-1$ & & & & \\
\hline
\end{tabular}

\begin{tabular}{|c|c|c|c|c|c|c|c|c|c|c|}
\hline \# & $\begin{array}{c}\text { Temp. } \\
{[\mathrm{K}]}\end{array}$ & $\begin{array}{c}\text { Pressure } \\
\text { [Atm.] }\end{array}$ & $\mathrm{O}$ & $\mathrm{O}_{2}$ & $\mathrm{NO}$ & $\mathrm{C}_{2} \mathrm{H}_{2}$ & $\mathrm{HCN}$ & $\mathrm{C}_{2} \mathrm{H}$ & $\mathrm{C}_{3}$ & $\mathrm{CN}$ \\
\hline 1 & 750.0 & 0.00014 & & & & & & & & \\
\hline 2 & 750.0 & 0.00041 & & & & & & & & \\
\hline 3 & 813.8 & 0.02400 & & & & & & & & \\
\hline 4 & 859.8 & 0.08732 & & & & & & & & \\
\hline 5 & 892.4 & 0.11167 & & & & & & & & \\
\hline 6 & 1500 & 0.00327 & & & $5.22 \mathrm{E}-2$ & $2.93 \mathrm{E}-2$ & & & & \\
\hline 7 & 1750 & 0.288 & $1.60 \mathrm{E}-1$ & $3.22 \mathrm{E}-3$ & & & & & & \\
\hline 8 & 2000 & 0.14693 & $6.00 \mathrm{E}-4$ & $1.20 \mathrm{E}-1$ & $5.99 \mathrm{E}-3$ & & & & & \\
\hline 9 & 2250 & 0.03136 & & & & & & & & \\
\hline 10 & 2250 & 0.04711 & & & & & & & & \\
\hline 11 & 2250 & 0.23807 & $2.82 \mathrm{E}-3$ & $1.41 \mathrm{E}-1$ & $1.20 \mathrm{E}-2$ & & & & & \\
\hline 12 & 2750 & 0.01849 & $1.10 \mathrm{E}-2$ & $1.15 \mathrm{E}-3$ & $1.96 \mathrm{E}-3$ & & & & & \\
\hline 13 & 2750 & 0.13282 & $1.33 \mathrm{E}-2$ & $1.21 \mathrm{E}-2$ & $7.53 \mathrm{E}-3$ & & & & & \\
\hline 14 & 3042 & 0.19887 & $4.42 \mathrm{E}-2$ & $3.07 \mathrm{E}-2$ & $1.69 \mathrm{E}-2$ & & & & & \\
\hline 15 & 3211 & 0.23030 & $9.16 \mathrm{E}-2$ & $3.13 \mathrm{E}-2$ & $2.24 \mathrm{E}-2$ & & & & & \\
\hline 16 & 3220 & 0.36700 & $8.83 \mathrm{E}-2$ & $4.64 \mathrm{E}-2$ & $2.79 \mathrm{E}-2$ & & & & & \\
\hline 17 & 3307 & 0.19600 & & & & $7.29 \mathrm{E}-3$ & $4.60 \mathrm{E}-2$ & $6.83 \mathrm{E}-2$ & $4.46 \mathrm{E}-2$ & $4.25 \mathrm{E}-2$ \\
\hline
\end{tabular}

Table 2. Nominal input conditions for the test-case for ablating carbon-phenolic Ref. 1

\begin{tabular}{rcccc}
\hline \hline & Oxygen & Nitrogen & Hydrogen & Carbon \\
\hline Boundary layer edge gas & $76.7 \%$ & $23.3 \%$ & $0.0 \%$ & $0.0 \%$ \\
Pyrolysis gas & $32.7 \%$ & $0.0 \%$ & $12.4 \%$ & $54.9 \%$ \\
Fully charred solid & $0.0 \%$ & $0.0 \%$ & $0.0 \%$ & $100.0 \%$ \\
\hline \hline
\end{tabular}




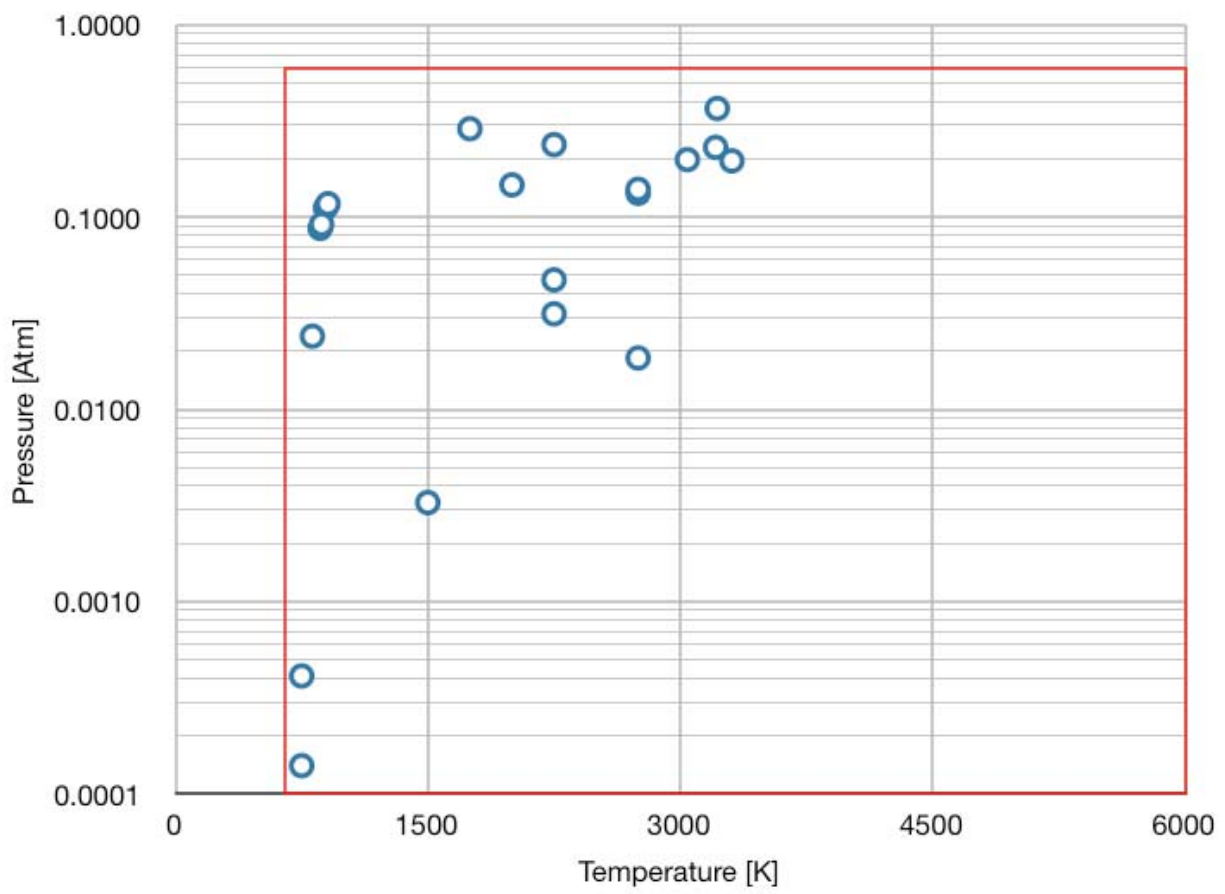

Figure 1. Temperature vs. Pressure for various surface locations, trajectory points and re-entry vehicles

well as the elemental mass balance. Using this method, the following species are selected (excluding air species):

$$
\mathrm{H}_{2}, \mathrm{CO}, \mathrm{CH}_{4}, \mathrm{H}_{2} \mathrm{O}, \mathrm{CO}_{2}, \mathrm{OH}, \mathrm{C}_{2} \mathrm{H}, \mathrm{C}_{2} \mathrm{H}_{2}, \mathrm{C}_{3}, \mathrm{CN}
$$

It is to be noted that this methodology is not respected for the trajectory point 17; in this case, the error is approximately $4 \%$. This is due to the fact that the JANNAF thermodynamic database, used by MAT, is outdated and gives inconsistent results for some situations. For instance, the $\mathrm{C}_{6} \mathrm{H}$ molecule was present, even though it should not appear from the equilibrium decomposition of phenol.

\section{Boundary layer species}

Ablation species are likely to be broken down as they travel through the boundary layer and in the post-shock layer. Therefore, it is important to include possible reaction paths leading to smaller molecules, as well as species from important reactions. This requires consideration of:

$$
\mathrm{H}, \mathrm{NH}, \mathrm{HO}_{2}, \mathrm{H}_{2} \mathrm{O}_{2}, \mathrm{C}_{2} \mathrm{O}, \mathrm{HCN}, \mathrm{HCO}
$$

as well as the hydrocarbon species:

$$
\mathrm{C}, \mathrm{C}_{2}, \mathrm{CH}, \mathrm{CH}_{2}, \mathrm{CH}_{3}, \mathrm{C}_{2} \mathrm{H}_{6}, \mathrm{C}_{2} \mathrm{H}_{5}, \mathrm{C}_{2} \mathrm{H}_{4}, \mathrm{C}_{2} \mathrm{H}_{3}
$$

Because this type of heat shield is mainly used to accommodate very high speed re-entries, such as Stardust, it is important to include the main ionized species. Even though the ionization process will occur in the shock layer, the charged particles could potentially still reach the boundary layer. Additionally, through associative ionization, electron-impact ionization and, especially, charge exchange reactions, some of the carbon species could be ionized. Therefore, the following species are included:

$$
\mathrm{CN}^{+}, \mathrm{CO}^{+}, \mathrm{C}^{+}, \mathrm{H}^{+}
$$


The following molecules are also added to the set because they are part of the chemical reactions that could be important when the pyrolysis gas is heated in the boundary layer:

$$
\mathrm{NNH}, \mathrm{HCCO}, \mathrm{NH}_{2}, \mathrm{NH}_{3}, \mathrm{NCO}, \mathrm{NO}_{2}, \mathrm{~N}_{2} \mathrm{O}, \mathrm{HNO}
$$

It is also noted that the following molecules are added to the model for experimental validations purposes:

$$
\mathrm{Ar}, \mathrm{Ar}^{+}, \mathrm{C}_{2} \mathrm{~N}_{2}, \mathrm{NCN}, \mathrm{C}_{2} \mathrm{~N}, \mathrm{C}_{3} \mathrm{O}_{2}
$$

Argon species are included because Argon is the usual carrier gas for most experiments of this type; these are not expected to impact the reaction mechanism. The other species are the initial "cold" species used in the experiments; they are not expected to be created while reacting with other species in the temperature and pressure range of interest, and they usually dissociate instantaneously when passing through the shock.

Therefore, the present complete model includes $\mathbf{5 5}$ species.

\section{B. Reaction selection}

Because phenolic vapor, produced by the pyrolysis of carbon-phenolic, is very similar reaction wise to a combustion problem, the rates gathered from that field are used as a basis for the complete model. Because it is accurate, complete, and comprehensive, the GRI-MECH database, ${ }^{19}$ built by The University of California at Berkeley, Stanford University and The University of Texas at Austin, has been chosen. One of the problems with those rates is that they are only valid up to $5000 \mathrm{~K}$, which is not a sufficient temperature range for the gases out of the boundary layer. However, since the pyrolysis gases are not expected to enter regions of the flow where higher temperatures are reached (i.e. the shock layer), this assumption is valid for the current application. To account for the gases that are present in high temperature regions, reaction rates relevant to those regions are replaced by those from Ref. 1 and Ref. 10, which were validated across a wide temperature range. Some reaction rates, taken from recent publications, were also added or replaced in the base model. This model, not presented here, is composed of $\mathbf{2 4 0}$ reactions.

\section{Validation}

In order to validate and help select the appropriate kinetic rates for a reduced model, results from a series of shock tubes experiments are chosen and compared with results from the numerical model. The experiments selected have test conditions that are relevant to an ablating boundary layer environment, and highlight kinetic rates and molecules that are important to the model. Most of these experiments were used to compute some of the chosen rates, but their ranges of validity might be limited. Therefore, the objective is to select rates that give satisfactory agreements with data from a wide range of experiments. To illustrate this effort, the reaction $\mathrm{CN}+\mathrm{O} \rightleftharpoons \mathrm{CO}+\mathrm{N}$ is used. Since $\mathrm{CN}$ is a strong radiator, this reaction is one of the most important, and therefore, many experiments were designed to try to determine its reaction rates. Seven of those rates are selected (listed in Table 3), and compared to two different experiments, using the complete chemistry model described in the previous section.

Table 3. Tested reactions

\begin{tabular}{ccccl}
\hline \hline Reactions & $\mathrm{A}[\mathrm{mole} /(\mathrm{cm} \mathrm{s})]$ & $\mathrm{n}$ & $T_{a}[\mathrm{~K}]$ & Source \\
\hline $\mathrm{CN}+\mathrm{O} \rightleftharpoons \mathrm{CO}+\mathrm{N}$ & $2.04 \times 10^{13}$ & 0.0 & 210.0 & Louge and Hanson $(84)^{20}$ \\
$\mathrm{CN}+\mathrm{O} \rightleftharpoons \mathrm{CO}+\mathrm{N}$ & $3.00 \times 10^{13}$ & 0.0 & 0.0 & Mozzhukin, Burmeister and Roth $(89)^{21}$ \\
$\mathrm{CN}+\mathrm{O} \rightleftharpoons \mathrm{CO}+\mathrm{N}$ & $6.20 \times 10^{12}$ & 0.0 & -1000.0 & Lindackers, Burmeister and Roth $(90)^{22}$ \\
$\mathrm{CN}+\mathrm{O} \rightleftharpoons \mathrm{CO}+\mathrm{N}$ & $7.70 \times 10^{13}$ & 0.0 & 0.0 & Davidson, Dean, DiRosa and Hanson $(91)^{23}$ \\
$\mathrm{CN}+\mathrm{O} \rightleftharpoons \mathrm{CO}+\mathrm{N}$ & $1.02 \times 10^{13}$ & 0.0 & 0.0 & Baulch et al. $(92)^{24}$ \\
$\mathrm{CO}+\mathrm{N} \rightleftharpoons \mathrm{CN}+\mathrm{O}$ & $1.00 \times 10^{14}$ & 0.0 & 38600.0 & Park, Jaffe and Partridge $(01)^{1}$ \\
$\mathrm{CO}+\mathrm{N} \rightleftharpoons \mathrm{CN}+\mathrm{O}$ & $2.41 \times 10^{14}$ & -0.18 & 0.0 & Andersson, Markovic and Nyman $(04)^{25}$ \\
\hline \hline
\end{tabular}

As can be seen in Fig. 2, for experiments that are specifically designed to highlight the effects of these kinetic rates, changes in one rate, at those specific experimental conditions, correspond to a wide range of 
results. The objective therefore is to choose a rate that has been validated over the widest temperature and pressure ranges, and that gives the best matches when compared to multiple experimental data. As seen on the figure, this is not necessarily an easy task, as certain rates provide a good fit with one data set but a poor fit with another. In this particular case, it seems appropriate to focus on the agreement for the CN species than to focus on $\mathrm{O}$, as $\mathrm{CN}$ tends to be more radiative. Consideration of relative errors also helps to select the best rate; for instance, since the $\mathrm{CN}$ mole fraction rapidly goes zero, the relative error becomes very large, which is not the case in the other figure. Finally, it is also important to consider the experimental conditions used to determine the rate, especially to determine whether the temperature and pressure range is valid for the problem at hand. In this particular case, the theoretical rate computed by Ref. 25 was chosen for the above reasons, as well as for the multiple experimental validations which they performed and presented.

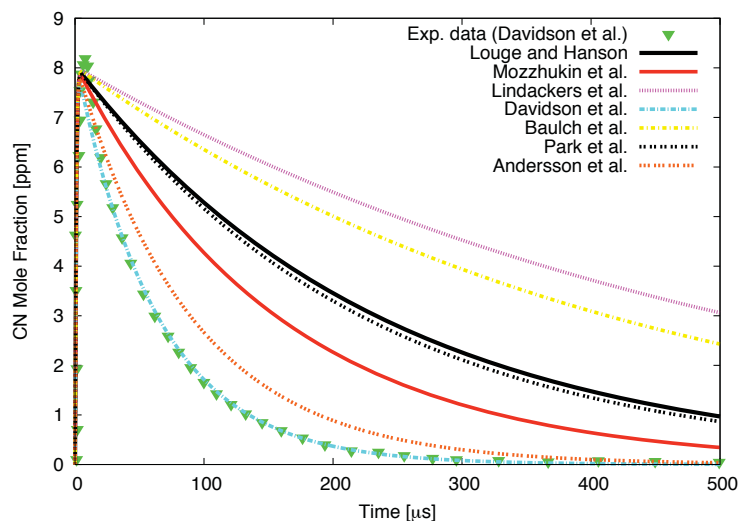

(a) Comparison to the experiment of Ref. 23: $T=4020 \mathrm{~K}$, $p=0.682 \mathrm{~atm}, 4 \mathrm{ppm}$ of $\mathrm{C}_{2} \mathrm{~N}_{2}$ and $100 \mathrm{ppm}$ of $\mathrm{N}_{2} \mathrm{O}$ in Argon

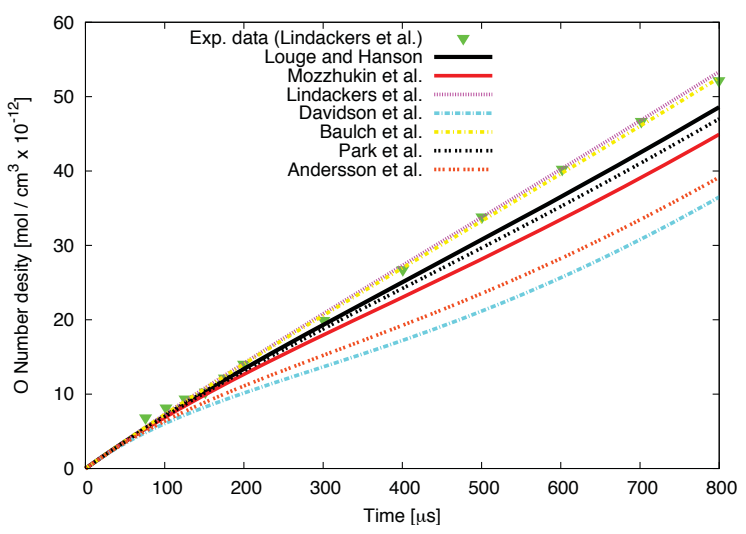

(b) Comparison to the experiment of Ref. 22: $T=2966$ $\mathrm{K}, p=1.579 \mathrm{~atm}, 5 \mathrm{ppm}$ of $\mathrm{C}_{2} \mathrm{~N}_{2}$ and $250 \mathrm{ppm}$ of $\mathrm{CO}_{2}$ in Argon

Figure 2. Comparison with experiments of various kinetic rates for the $\mathrm{CN}+\mathrm{O} \rightleftharpoons \mathrm{CO}+\mathrm{N}$ reaction

\section{Experimental comparisons}

In order to validate the proposed complete model, multiple zero dimensional simulations are performed using the CHEMKIN ${ }^{26}$ package, and compared to available experimental data. The experiments presented here are selected because they are typical of an ablative boundary layer during hypersonic re-entry. As can be seen in Fig. 3, the model fits the data remarkably well, which is expected since some of the presented experiments were employed to validate and even compute the kinetic rates used in the model. The discrepancy observed in some of the graphs, FIg. 3b), c) and f), in particular, is caused by the choice of a different reaction rate than the one obtained from the experimental data. As shown earlier, the results from changing one kinetic rate can have a non trivial impact on the concentration of the species over time. A detailed explanation of this is presented in. ${ }^{10}$ The results presented here, although not perfect, are considered to agree remarkably well with the experimental data.

\section{Reduced model}

\section{A. Species and reactions selection}

Following the methodology developed in Ref. 10 for Titan atmospheric entries, the complete model is simplified to a reduced model. In order to do so, a sensitivity analysis is performed using the software SENKIN, part of the CHEMKIN package. ${ }^{26}$ SENKIN performs a non-linear sensitivity analysis on the rate coefficients and output the results on the form of normalized maximum sensitivity parameter $S$. For each reaction $r, S$ is computed over time using:

$$
S_{t, r}=\frac{k_{r}}{X_{\max }} \frac{\partial X_{t}}{\partial k_{r}}
$$




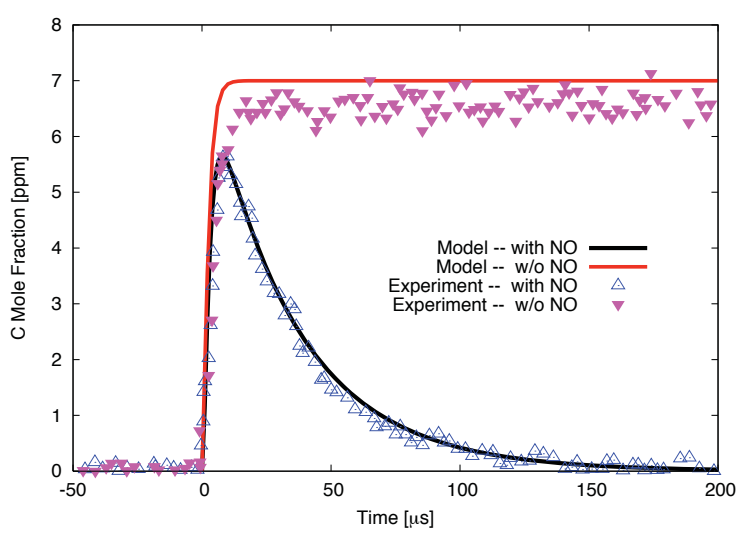

(a) Comparison to the experiment of Ref. 27: $T=2864 \mathrm{~K}$, $p=1.00 \mathrm{~atm}, 7 \mathrm{ppm}$ of $\mathrm{C}_{3} \mathrm{O}_{2}$ and $147 \mathrm{ppm}$ of $\mathrm{NO}$ in Argon

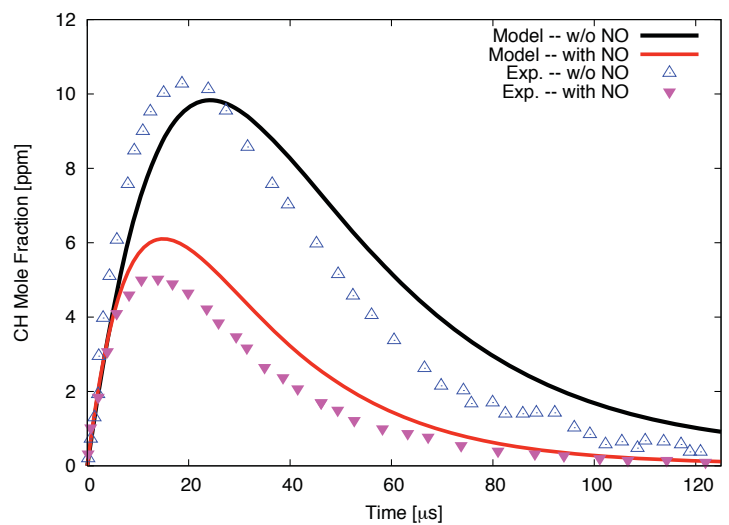

(c) Comparison to the experiment of Ref. 27: $T=3287$ $\mathrm{K}, p=0.67 \mathrm{~atm}, 20 \mathrm{ppm}$ of $\mathrm{C}_{2} \mathrm{H}_{6}$ and $300 \mathrm{ppm}$ of $\mathrm{NO}$ in Argon

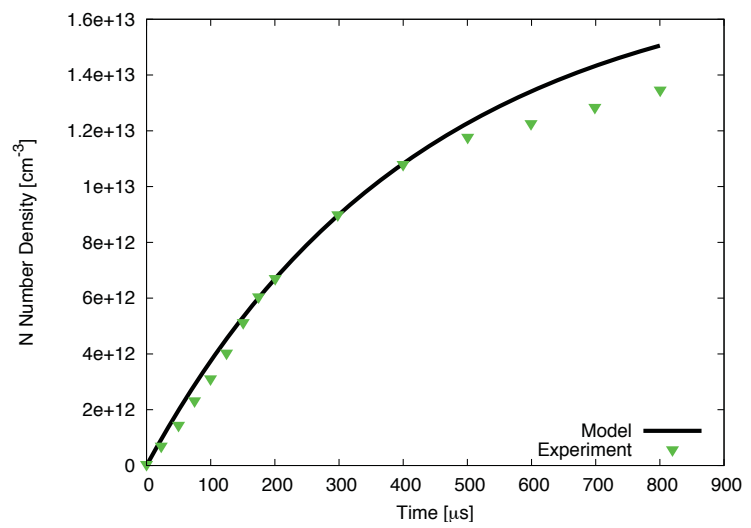

(e) Comparison to the experiment of Ref. 28: $T=5290 \mathrm{~K}$, $p=1.88 \mathrm{~atm}, 5 \mathrm{ppm}$ of $\mathrm{C}_{2} \mathrm{~N}_{2}$ in Argon

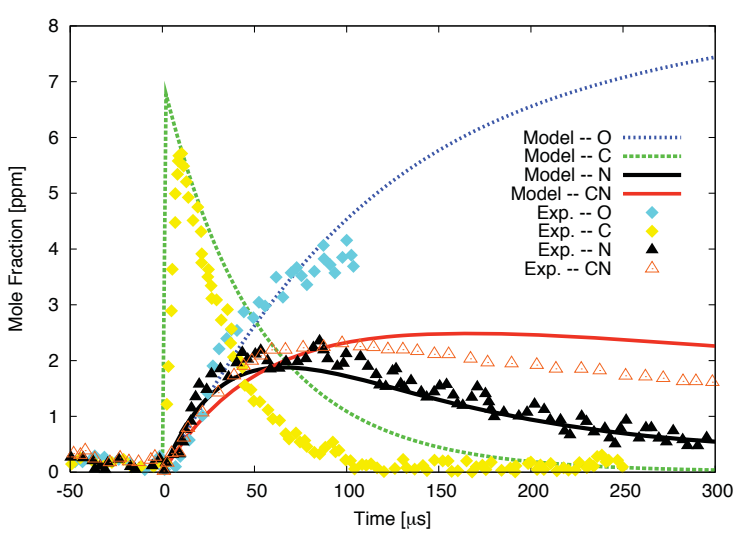

(b) Comparison to the experiment of Ref. 27: $T=3620$ $\mathrm{K}, p=0.80$ atm, $7 \mathrm{ppm}$ of $\mathrm{C}_{3} \mathrm{O}_{2}$ and $147 \mathrm{ppm}$ of $\mathrm{NO}$ in Argon

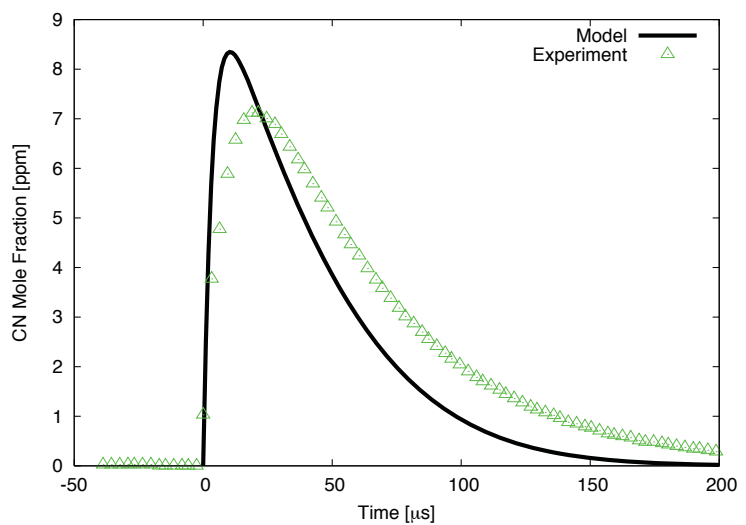

(d) Comparison to the experiment of Ref. 23: $T=3470$ $\mathrm{K}, p=0.835 \mathrm{~atm}, 5 \mathrm{ppm}$ of $\mathrm{C}_{2} \mathrm{~N}_{2}$ and $515 \mathrm{ppm}$ of $\mathrm{O}_{2}$ in Argon

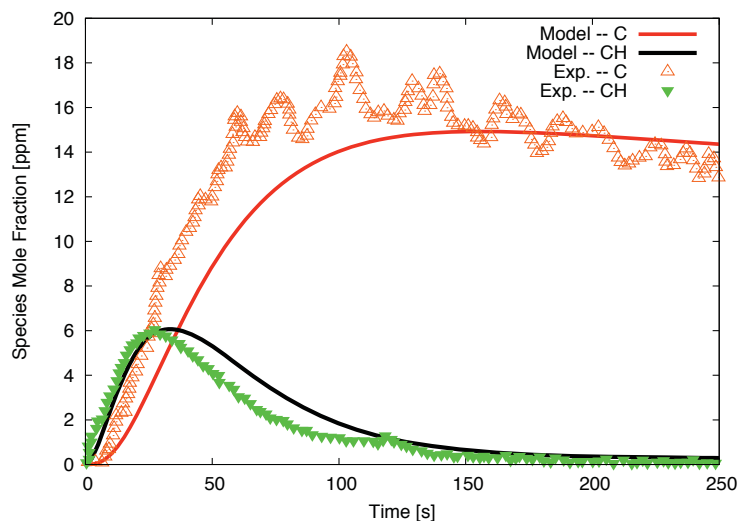

(f) Comparison to the experiment of Ref. 29: $T=3100 \mathrm{~K}$, $p=0.89$ atm, $30 \mathrm{ppm}$ of $\mathrm{CH}_{4}$ in Argon

Figure 3. Validation of the complete model using experimental data 
Where $X_{t}$ represent the parameter onto which the sensitivity analysis has been performed at time $t$, and $k_{r}$ is the kinetic rate of reaction $r$. $X_{\max }$ is chosen as the maximum value of $X_{t}$ over the simulated time. The parameters deemed relevant for ablating Earth entry are the temperature and the number density of CN, $\mathrm{CO}, \mathrm{H}_{2} \mathrm{O}$ and $\mathrm{OH}$.

Validation is performed via a zero dimensional analysis. In order to perform a sensitivity analysis, a parameter space based on temperature, pressure and gas composition is defined. Thermogravimetric analysis (TGA) indicates that the onset temperature of pyrolyis for PICA in air is around $560 \mathrm{~K}$ while in argon is around $650 \mathrm{~K}^{30}$ Thus, for the purpose of the current analysis, a lower temperature boundary of $700 \mathrm{~K}$ was chosen. Because the ablating gas is not expected to leave the boundary layer, the value of $6000 \mathrm{~K}$ is selected for the upper temperature value. For the pressure, a minimum of $1 \times 10^{-4} \mathrm{~atm}$ and a maximum of $0.5 \mathrm{~atm}$ is chosen; these values are based on the re-entry trajectories presented (partially) in Fig. 1. The red square in that figure illustrates this parameter space.

Figure 4 shows an example of this type of analysis; only the reactions that have a sensitivity of $1 \%$ of the maximum sensitivity are shown.

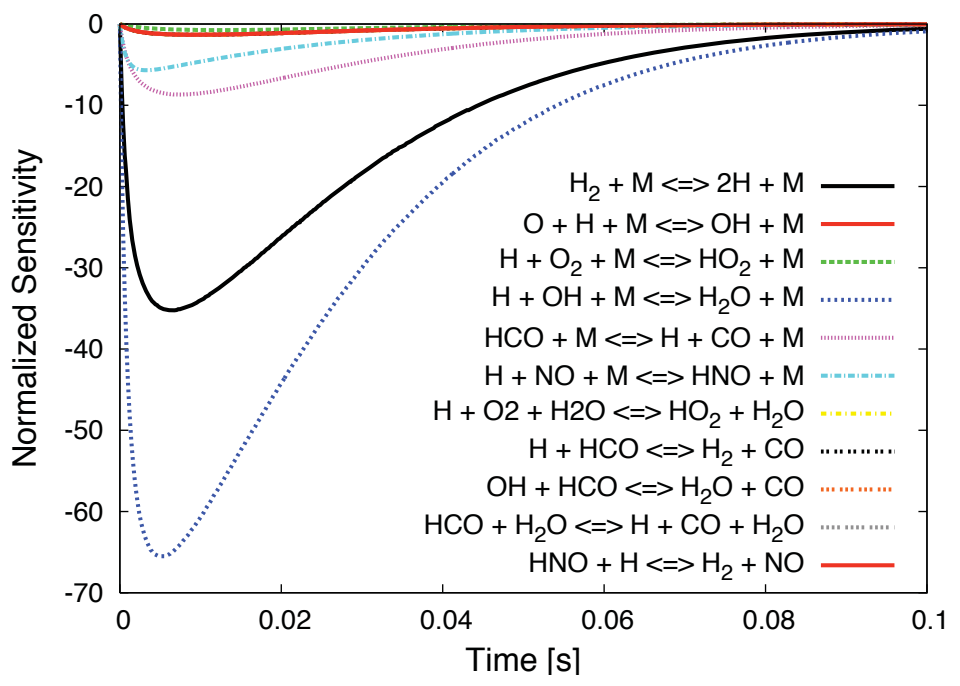

Figure 4. Temperature sensitivity analysis for the complete model: $\mathrm{T}=3250 \mathrm{~K}$ and $\mathrm{P}=0.5$ atm, with a initial composition compute from a Stardust re-entry equilibrium wall. Only the reactions with more than $1 \%$ of maximum sensitivity values are shown.

The sensitivity analysis is also used to eliminate the unimportant species based on the criterion that these species have a molar concentration of no more than $1 \%$. From this analysis, the species that are kept are:

$$
\mathrm{C}_{2} \mathrm{H}, \mathrm{C}_{2} \mathrm{H}_{2}, \mathrm{C}_{3}, \mathrm{CH}_{3}, \mathrm{CH}_{4}, \mathrm{CO}, \mathrm{CO}_{2}, \mathrm{H}, \mathrm{H}_{2}, \mathrm{H}_{2} \mathrm{O}, \mathrm{HCN}, \mathrm{N}, \mathrm{N}_{2}, \mathrm{NO}, \mathrm{O}, \mathrm{O}_{2}, \mathrm{OH}
$$

The ionized air species also need to be kept because of their presence in the shock layer (which is not part of this analysis), as well as their possible interaction with boundary layer species. Therefore, the following are also kept:

$$
\mathrm{N}_{2}^{+}, \mathrm{N}^{+}, \mathrm{O}^{+}, \mathrm{NO}^{+}, \mathrm{O}_{2}^{+}, \mathrm{CO}^{+}, \mathrm{C}^{+}, \mathrm{H}^{+} \mathrm{e}^{-}
$$

As mentioned earlier, some molecules do not exist in significant concentration, but allow important, if not crucial, reactions to take place, and therefore, need to be present in the models. The species that are deemed important are:

$$
\mathrm{CH}, \mathrm{CH}_{2}, \mathrm{C}, \mathrm{C}_{2}, \mathrm{NCO}, \mathrm{NH}, \mathrm{HNO}, \mathrm{HCO}, \mathrm{H}_{2} \mathrm{O}_{2}, \mathrm{HO}_{2}
$$

Finally, because of their radiative properties, the following species are also included in the reduced model:

$$
\mathrm{CN}, \mathrm{CN}^{+}
$$

The model therefore contains $\mathbf{3 8}$ species. 
Using the present sensitivity analysis, it is possible to significantly reduce the number of chemical equations in the model. Therefore, the equations that provide a relative sensitivity of less than $1 \%$ of the maximum overall sensitivity (Fig. 4) are removed. The $\mathbf{1 5 2}$ reactions considered are listed in Table 4; the kinetic rates $k$ are presented in a modified Arrhenius format, using the following equation:

$$
k=A T^{n} e^{-T_{a} / T}
$$

Table 4: Considered reactions for the atmospheric ablating PICA chemistry model

\begin{tabular}{|c|c|c|c|c|c|}
\hline \# & Reactions & $\mathrm{A}[\mathrm{mole} /(\mathrm{cm} \mathrm{s})]$ & $\mathrm{n}$ & $T_{a}[\mathrm{~K}]$ & Refereces \\
\hline 1 & $2 \mathrm{HO}_{2} \rightleftharpoons \mathrm{O}_{2}+\mathrm{H}_{2} \mathrm{O}_{2}$ & $4.20 \times 10^{14}$ & 0.0 & 6042.7 & 19 \\
\hline \multirow[t]{6}{*}{2} & $2 \mathrm{OH}+\mathrm{M} \rightleftharpoons \mathrm{H}_{2} \mathrm{O}_{2}+\mathrm{M}$ & $2.30 \times 10^{18}$ & -0.9 & -1700.0 & 19 \\
\hline & & $\mathrm{H}_{2}$ enhanced by 2.00 & & & \\
\hline & & $\mathrm{H}_{2} \mathrm{O}$ enhanced by 6.00 & & & \\
\hline & & $\mathrm{CH}_{4}$ enhanced by 2.00 & & & \\
\hline & & $\mathrm{CO}$ enhanced by 1.50 & & & \\
\hline & & $\mathrm{CO}_{2}$ enhanced by 2.00 & & & \\
\hline 3 & $2 \mathrm{OH} \rightleftharpoons \mathrm{O}+\mathrm{H}_{2} \mathrm{O}$ & $3.57 \times 10^{4}$ & 2.4 & -1062.5 & 19 \\
\hline 4 & $\mathrm{C}+\mathrm{H}_{2} \rightleftharpoons \mathrm{CH}+\mathrm{H}$ & $4.00 \times 10^{14}$ & 0.0 & 11700.0 & 31 \\
\hline 5 & $\mathrm{C}+\mathrm{N}_{2} \rightleftharpoons \mathrm{CN}+\mathrm{N}$ & $5.24 \times 10^{13}$ & 0.0 & 22600.0 & 32 \\
\hline 6 & $\mathrm{C}+\mathrm{NO} \rightleftharpoons \mathrm{CN}+\mathrm{O}$ & $2.02 \times 10^{14}$ & -0.3 & 0.0 & 25 \\
\hline 7 & $\mathrm{C}+\mathrm{NO} \rightleftharpoons \mathrm{CO}+\mathrm{N}$ & $2.29 \times 10^{13}$ & 0.0 & 0.0 & 25 \\
\hline 8 & $\mathrm{C}+\mathrm{O} \rightleftharpoons \mathrm{CO}^{+}+\mathrm{e}^{-}$ & $8.80 \times 10^{8}$ & 1.0 & 33100.0 & 1 \\
\hline 9 & $\mathrm{C}+\mathrm{O}_{2} \rightleftharpoons \mathrm{O}+\mathrm{CO}$ & $5.80 \times 10^{13}$ & 0.0 & 576.0 & 19 \\
\hline 10 & $\mathrm{C}_{2}+\mathrm{C}_{2} \rightleftharpoons \mathrm{C}_{3}+\mathrm{C}$ & $3.20 \times 10^{14}$ & 0.0 & 0.0 & 33 \\
\hline 11 & $\mathrm{C}_{2}+\mathrm{H}_{2} \rightleftharpoons \mathrm{C}_{2} \mathrm{H}+\mathrm{H}$ & $6.60 \times 10^{13}$ & 0.0 & 4030.0 & 33 \\
\hline 12 & $\mathrm{C}_{2}+\mathrm{N}_{2} \rightleftharpoons \mathrm{CN}+\mathrm{CN}$ & $1.50 \times 10^{13}$ & 0.0 & 21000.0 & 34 \\
\hline 13 & $\mathrm{C}_{2} \mathrm{H}+\mathrm{M} \rightleftharpoons \mathrm{C}_{2}+\mathrm{H}+\mathrm{M}$ & $1.74 \times 10^{35}$ & -5.2 & 57400.0 & 33 \\
\hline 14 & $\mathrm{C}_{2} \mathrm{H}+\mathrm{C} \rightleftharpoons \mathrm{C}_{3}+\mathrm{H}$ & $1.00 \times 10^{14}$ & 0.0 & 0.0 & 35 \\
\hline 15 & $\mathrm{C}_{2} \mathrm{H}_{2}+\mathrm{M} \rightleftharpoons \mathrm{C}_{2} \mathrm{H}+\mathrm{H}+\mathrm{M}$ & $6.96 \times 10^{39}$ & -6.1 & 67130.0 & 33 \\
\hline 16 & $\mathrm{CH}+\mathrm{C} \rightleftharpoons \mathrm{C}_{2}+\mathrm{H}$ & $2.00 \times 10^{14}$ & 0.0 & 0.0 & 35 \\
\hline 17 & $\mathrm{CH}+\mathrm{CH} \rightleftharpoons \mathrm{C}_{2} \mathrm{H}+\mathrm{H}$ & $1.50 \times 10^{14}$ & 0.0 & 0.0 & 35 \\
\hline 18 & $\mathrm{CH}+\mathrm{CO}_{2} \rightleftharpoons \mathrm{HCO}+\mathrm{CO}$ & $1.90 \times 10^{14}$ & 0.0 & 7952.1 & 19 \\
\hline 19 & $\mathrm{CH}+\mathrm{M} \rightleftharpoons \mathrm{C}+\mathrm{H}+\mathrm{M}$ & $1.90 \times 10^{14}$ & 0.0 & 33700.0 & 35 \\
\hline 20 & $\mathrm{CH}+\mathrm{N}_{2} \rightleftharpoons \mathrm{HCN}+\mathrm{N}$ & $4.40 \times 10^{12}$ & 0.0 & 11060.0 & 36 \\
\hline 21 & $\mathrm{CH}+\mathrm{O}_{2} \rightleftharpoons \mathrm{O}+\mathrm{HCO}$ & $6.71 \times 10^{13}$ & 0.0 & 0.0 & 19 \\
\hline 22 & $\mathrm{CH}_{2}+\mathrm{C} \rightleftharpoons \mathrm{C}_{2} \mathrm{H}+\mathrm{H}$ & $5.00 \times 10^{13}$ & 0.0 & 0.0 & 35 \\
\hline 23 & $\mathrm{CH}_{2}+\mathrm{CH} \rightleftharpoons \mathrm{C}_{2} \mathrm{H}_{2}+\mathrm{H}$ & $4.00 \times 10^{13}$ & 0.0 & 0.0 & 35 \\
\hline 24 & $\mathrm{CH}_{2}+\mathrm{CH}_{2} \rightleftharpoons \mathrm{C}_{2} \mathrm{H}_{2}+\mathrm{H}+\mathrm{H}$ & $2.00 \times 10^{14}$ & 0.0 & 5530.0 & 37 \\
\hline 25 & $\mathrm{CH}_{2}+\mathrm{CH}_{2} \rightleftharpoons \mathrm{C}_{2} \mathrm{H}_{2}+\mathrm{H}_{2}$ & $1.58 \times 10^{15}$ & 0.0 & 6010.0 & 37 \\
\hline 26 & $\mathrm{CH}_{2}+\mathrm{CH}_{4} \rightleftharpoons \mathrm{CH}_{3}+\mathrm{CH}_{3}$ & $4.30 \times 10^{12}$ & 0.00 & 5050.0 & 38 \\
\hline 27 & $\mathrm{CH}_{2}+\mathrm{H} \rightleftharpoons \mathrm{CH}+\mathrm{H}_{2}$ & $6.03 \times 10^{12}$ & 0.0 & -900.0 & 24 \\
\hline 28 & $\mathrm{CH}_{2}+\mathrm{M} \rightleftharpoons \mathrm{C}+\mathrm{H}_{2}+\mathrm{M}$ & $1.30 \times 10^{14}$ & 0.0 & 29700.0 & 35 \\
\hline 29 & $\mathrm{CH}_{2}+\mathrm{M} \rightleftharpoons \mathrm{CH}+\mathrm{H}+\mathrm{M}$ & $4.00 \times 10^{15}$ & 0.0 & 41800.0 & 35 \\
\hline 30 & $\mathrm{CH}_{2}+\mathrm{N} \rightleftharpoons \mathrm{HCN}+\mathrm{H}$ & $5.00 \times 10^{13}$ & 0.0 & 0.0 & 36 \\
\hline 31 & $\mathrm{CH}_{2}+\mathrm{N}_{2} \rightleftharpoons \mathrm{HCN}+\mathrm{NH}$ & $4.82 \times 10^{12}$ & 0.0 & 18000.0 & 39 \\
\hline 32 & $\mathrm{CH}_{2}+\mathrm{NO} \rightleftharpoons \mathrm{OH}+\mathrm{HCN}$ & $2.90 \times 10^{14}$ & -0.69 & 382.70 & 19 \\
\hline 33 & $\mathrm{CH}_{3}+\mathrm{C} \rightleftharpoons \mathrm{C}_{2} \mathrm{H}_{2}+\mathrm{H}$ & $5.00 \times 10^{13}$ & 0.0 & 0.0 & 35 \\
\hline 34 & $\mathrm{CH}_{3}+\mathrm{H} \rightleftharpoons \mathrm{CH}_{2}+\mathrm{H}_{2}$ & $6.03 \times 10^{13}$ & 0.0 & 7600.0 & 24 \\
\hline 35 & $\mathrm{CH}_{3}+\mathrm{HCO} \rightleftharpoons \mathrm{CH}_{4}+\mathrm{CO}$ & $1.21 \times 10^{14}$ & 0.0 & 0.0 & 40 \\
\hline 36 & $\mathrm{CH}_{3}+\mathrm{M} \rightleftharpoons \mathrm{CH}+\mathrm{H}_{2}+\mathrm{M}$ & $5.00 \times 10^{15}$ & 0.0 & 42800.0 & 35 \\
\hline 37 & $\mathrm{CH}_{3}+\mathrm{M} \rightleftharpoons \mathrm{CH}_{2}+\mathrm{H}+\mathrm{M}$ & $1.02 \times 10^{16}$ & 0.0 & 45600.0 & 24 \\
\hline 38 & $\mathrm{CH}_{3}+\mathrm{N} \rightleftharpoons \mathrm{HCN}+\mathrm{H}+\mathrm{H}$ & $7.00 \times 10^{13}$ & 0.0 & 0.0 & 36 \\
\hline 39 & $\mathrm{CH}_{3}+\mathrm{N} \rightleftharpoons \mathrm{HCN}+\mathrm{H}_{2}$ & $3.70 \times 10^{12}$ & 0.1 & -45.3 & 19 \\
\hline 40 & $\mathrm{CH}_{3}+\mathrm{NO} \rightleftharpoons \mathrm{HCN}+\mathrm{H}_{2} \mathrm{O}$ & $9.60 \times 10^{13}$ & 0.00 & 14502.41 & 19 \\
\hline 41 & $\mathrm{CH}_{4}+\mathrm{M} \rightleftharpoons \mathrm{CH}_{3}+\mathrm{H}+\mathrm{M}$ & $4.70 \times 10^{47}$ & -8.2 & 59200.0 & 32 \\
\hline 42 & $\mathrm{CN}+\mathrm{C} \rightleftharpoons \mathrm{C}_{2}+\mathrm{N}$ & $5.00 \times 10^{13}$ & 0.0 & 13000.0 & 41 \\
\hline 43 & $\mathrm{CN}+\mathrm{CO} \rightleftharpoons \mathrm{C}+\mathrm{NCO}$ & $1.50 \times 10^{16}$ & -0.5 & 65800.0 & 1 \\
\hline 44 & $\mathrm{CN}+\mathrm{CO}_{2} \rightleftharpoons \mathrm{CO}+\mathrm{NCO}$ & $4.00 \times 10^{14}$ & 0.0 & 19200.0 & 1 \\
\hline 45 & $\mathrm{CN}+\mathrm{H}_{2} \rightleftharpoons \mathrm{HCN}+\mathrm{H}$ & $2.95 \times 10^{5}$ & 2.5 & 1130.0 & 19 \\
\hline 46 & $\mathrm{CN}+\mathrm{H}_{2} \mathrm{O} \rightleftharpoons \mathrm{HCN}+\mathrm{OH}$ & $8.00 \times 10^{12}$ & 0.0 & 3756.5 & 19 \\
\hline 47 & $\mathrm{CN}+\mathrm{M} \rightleftharpoons \mathrm{C}+\mathrm{N}+\mathrm{M}$ & $2.53 \times 10^{14}$ & 0.0 & 71000.0 & 41 \\
\hline 48 & $\mathrm{CN}+\mathrm{NO} \rightleftharpoons \mathrm{N}+\mathrm{NCO}$ & $2.00 \times 10^{13}$ & 0.0 & 21000.0 & 31 \\
\hline 49 & $\mathrm{CN}+\mathrm{O} \rightleftharpoons \mathrm{CO}+\mathrm{N}$ & $2.41 \times 10^{14}$ & -0.2 & 0.0 & 25 \\
\hline
\end{tabular}


Table 4 - continued from previous page

\begin{tabular}{|c|c|}
\hline$\#$ & Reactions \\
\hline 50 & $\mathrm{CN}+\mathrm{O}_{2} \rightleftharpoons \mathrm{O}+\mathrm{NCO}$ \\
\hline 51 & $\mathrm{CN}+\mathrm{OH} \rightleftharpoons \mathrm{NCO}+\mathrm{H}$ \\
\hline 52 & $\mathrm{CO}+\mathrm{C}^{+} \rightleftharpoons \mathrm{CO}^{+}+\mathrm{C}$ \\
\hline 53 & $\mathrm{CO}+\mathrm{M} \rightleftharpoons \mathrm{O}+\mathrm{C}+\mathrm{M}$ \\
\hline 54 & $\mathrm{CO}_{2}+\mathrm{M} \rightleftharpoons \mathrm{O}+\mathrm{CO}+\mathrm{M}$ \\
\hline 55 & $\mathrm{CO}_{2}+\mathrm{O} \rightleftharpoons \mathrm{CO}+\mathrm{O}_{2}$ \\
\hline 56 & $\mathrm{H}+2 \mathrm{O}_{2} \rightleftharpoons \mathrm{HO}_{2}+\mathrm{O}_{2}$ \\
\hline 57 & $\mathrm{H}+\mathrm{C}_{2} \mathrm{H}_{2} \rightleftharpoons \mathrm{C}_{2} \mathrm{H}+\mathrm{H}_{2}$ \\
\hline 58 & $\mathrm{H}+\mathrm{CH}_{4} \rightleftharpoons \mathrm{CH}_{3}+\mathrm{H}_{2}$ \\
\hline 59 & $\mathrm{H}+\mathrm{H}_{2} \mathrm{O}_{2} \rightleftharpoons \mathrm{HO}_{2}+\mathrm{H}_{2}$ \\
\hline 60 & $\mathrm{H}+\mathrm{H}_{2} \mathrm{O}_{2} \rightleftharpoons \mathrm{OH}+\mathrm{H}_{2} \mathrm{O}$ \\
\hline 61 & $\mathrm{H}+\mathrm{HCO} \rightleftharpoons \mathrm{H}_{2}+\mathrm{CO}$ \\
\hline 62 & $\mathrm{H}+\mathrm{HO}_{2} \rightleftharpoons 2 \mathrm{OH}$ \\
\hline 63 & $\mathrm{H}+\mathrm{HO}_{2} \rightleftharpoons \mathrm{O}+\mathrm{H}_{2} \mathrm{O}$ \\
\hline 64 & $\mathrm{H}+\mathrm{HO}_{2} \rightleftharpoons \mathrm{O}_{2}+\mathrm{H}_{2}$ \\
\hline 65 & $\mathrm{H}+\mathrm{N}_{2} \rightleftharpoons \mathrm{NH}+\mathrm{N}$ \\
\hline 66 & $\mathrm{H}+\mathrm{NO}+\mathrm{M} \rightleftharpoons \mathrm{HNO}+\mathrm{M}$ \\
\hline
\end{tabular}

$\begin{array}{lc}79 & \mathrm{HCO}+\mathrm{O}_{2} \rightleftharpoons \mathrm{HO}_{2}+\mathrm{CO} \\ 80 & \mathrm{HNO}+\mathrm{H} \rightleftharpoons \mathrm{H}_{2}+\mathrm{NO} \\ 81 & \mathrm{HNO}+\mathrm{O} \rightleftharpoons \mathrm{NO}+\mathrm{OH} \\ 82 & \mathrm{HNO}+\mathrm{O}_{2} \rightleftharpoons \mathrm{HO}_{2}+\mathrm{NO} \\ 83 & \mathrm{HNO}+\mathrm{OH} \rightleftharpoons \mathrm{NO}+\mathrm{H}_{2} \mathrm{O} \\ 84 & \mathrm{HO}_{2}+\mathrm{CO} \rightleftharpoons \mathrm{OH}+\mathrm{CO}_{2} \\ 85 & \mathrm{~N}+\mathrm{CO}_{2} \rightleftharpoons \mathrm{NO}+\mathrm{CO} \\ 86 & \mathrm{~N}+\mathrm{e}^{-} \rightleftharpoons \mathrm{N}^{+}+\mathrm{e}-+\mathrm{e}^{-} \\ 87 & \mathrm{~N}+\mathrm{H}_{2} \rightleftharpoons \mathrm{NH}+\mathrm{H} \\ 88 & \mathrm{~N}+\mathrm{N} \rightleftharpoons \mathrm{N}_{2}^{+}+\mathrm{e}^{-} \\ 89 & \mathrm{~N}+\mathrm{OH}^{+} \rightleftharpoons \mathrm{NO}+\mathrm{H} \\ 90 & \mathrm{~N}^{+}+\mathrm{N}_{2} \rightleftharpoons \mathrm{N}_{2}++\mathrm{N} \\ 91 & \mathrm{~N}_{2}+\mathrm{M}^{+} \rightleftharpoons \mathrm{N}+\mathrm{N}+\mathrm{M}\end{array}$

$$
\begin{gathered}
\mathrm{H}+\mathrm{O}_{2}+\mathrm{N}_{2} \rightleftharpoons \mathrm{HO}_{2}+\mathrm{N}_{2} \\
\mathrm{H}+\mathrm{O}_{2} \rightleftharpoons \mathrm{O}+\mathrm{OH} \\
\mathrm{H}+\mathrm{OH}+\mathrm{M} \rightleftharpoons \mathrm{H}_{2} \mathrm{O}+\mathrm{M}
\end{gathered}
$$

$$
\begin{gathered}
\mathrm{H}_{2}+\mathrm{M} \rightleftharpoons \mathrm{H}+\mathrm{H}+\mathrm{M} \\
\mathrm{HCN}+\mathrm{M} \rightleftharpoons \mathrm{CN}+\mathrm{H}+\mathrm{M} \\
\mathrm{HCN}+\mathrm{O} \rightleftharpoons \mathrm{CN}+\mathrm{OH} \\
\mathrm{HCN}+\mathrm{O} \rightleftharpoons \mathrm{NCO}+\mathrm{H} \\
\mathrm{HCN}+\mathrm{O} \rightleftharpoons \mathrm{NH}+\mathrm{CO} \\
\mathrm{HCO}+\mathrm{H}_{2} \mathrm{O} \rightleftharpoons \mathrm{H}+\mathrm{CO}+\mathrm{H}_{2} \mathrm{O} \\
\mathrm{HCO}+\mathrm{M} \rightleftharpoons \mathrm{H}+\mathrm{CO}+\mathrm{M}
\end{gathered}
$$

A $[\mathrm{mole} /(\mathrm{cm} \mathrm{s})]$

$1.05 \times 10^{13}$

$4.00 \times 10^{13}$

$1.0 \times 10^{13}$

$2.30 \times 10^{19}$

$\mathrm{C}$ enhanced by 1.50

$\mathrm{N}$ enhanced by 1.50

O enhanced by 1.50

$\mathrm{H}$ enhanced by 1.50

$3.50 \times 10^{14}$

$2.10 \times 10^{13}$

$2.08 \times 10^{19}$

$6.62 \times 10^{13}$

$1.32 \times 10^{4}$

$1.21 \times 10^{7}$

$1.00 \times 10^{13}$

$7.34 \times 10^{13}$

$8.40 \times 10^{13}$

$3.97 \times 10^{12}$

$4.48 \times 10^{13}$

$1.84 \times 10^{13}$

$4.48 \times 10^{19}$

$\mathrm{H}_{2}$ enhanced by 2.00

$\mathrm{H}_{2} \mathrm{O}$ enhanced by 6.00

$\mathrm{CH}_{4}$ enhanced by 2.00

CO enhanced by 1.50

$\mathrm{CO}_{2}$ enhanced by 2.00

$$
1.13 \times 10^{19}
$$

$2.80 \times 10^{18}$

$\mathrm{O}_{2}$ enhanced by 0.00

$\mathrm{H}_{2} \mathrm{O}$ enhanced by 0.00

$\mathrm{CO}$ enhanced by 0.75

$\mathrm{CO}_{2}$ enhanced by 1.50

$\mathrm{N}_{2}$ enhanced by 0.00

$$
\begin{aligned}
& 2.60 \times 10^{19} \\
& 2.65 \times 10^{16}
\end{aligned}
$$

$2.20 \times 10^{22}$

$\mathrm{H}_{2}$ enhanced by 0.73

$\mathrm{H}_{2} \mathrm{O}$ enhanced by 3.65

$\mathrm{CH}_{4}$ enhanced by 2.00

$\begin{array}{cccc}2.23 \times 10^{14} & 0.0 & 48350.0 & 32 \\ 3.57 \times 10^{26} & -2.6 & 62845.0 & 43 \\ 3.91 \times 10^{9} & 1.6 & 13394.6 & 19 \\ 2.03 \times 10^{4} & 2.6 & 2507.7 & 19 \\ 5.07 \times 10^{3} & 2.6 & 2507.7 & 19 \\ 1.50 \times 10^{18} & -1.0 & 8560.5 & 19 \\ 1.87 \times 10^{17} & -1.0 & 8560.5 & 19\end{array}$

$\mathrm{H}_{2}$ enhanced by 2.00

$\mathrm{H}_{2} \mathrm{O}$ enhanced by 6.00

$\mathrm{CH}_{4}$ enhanced by 2.00

CO enhanced by 1.50

$\mathrm{CO}_{2}$ enhanced by 2.00

$\begin{array}{cccc}1.34 \times 10^{13} & 0.0 & 201.4 & 19 \\ 9.00 \times 10^{11} & 0.7 & 332.4 & 19 \\ 2.50 \times 10^{13} & 0.0 & 0.0 & 19 \\ 1.00 \times 10^{13} & 0.0 & 6546.2 & 19 \\ 1.30 \times 10^{7} & 1.9 & -478.4 & 19 \\ 1.50 \times 10^{14} & 0.0 & 11883.9 & 19 \\ 3.00 \times 10^{12} & 0.0 & 5690.2 & 19 \\ 2.5 \times 10^{34} & -3.82 & 168600.0 & 1 \\ 1.60 \times 10^{14} & 0.0 & 12650.0 & 23 \\ 2.0 \times 10^{13} & 0.00 & 67500 . & 44 \\ 3.36 \times 10^{13} & 0.0 & 193.9 & 19 \\ 1.0 \times 10^{12} & 0.50 & 12200.0 & 44 \\ 7.00 \times 10^{21} & -1.6 & 113200.0 & 1\end{array}$

Continued on next page

$\begin{array}{ccc}\mathrm{n} & T_{a}[\mathrm{~K}] & \text { Refereces } \\ 0.0 & 0.0 & 23 \\ 0.0 & 0.0 & 19 \\ 0.00 & 31400.0 & 41 \\ -1.0 & 129000.0 & 41\end{array}$

$\begin{array}{ccc}0.0 & 52525.0 & 22 \\ 0.0 & 27800.0 & 1 \\ -1.2 & 0.0 & 19 \\ 0.0 & 14000.0 & \\ 3.0 & 4045.0 & \\ 2.0 & 2618.5 & 19 \\ 0.0 & 1812.8 & 19 \\ 0.0 & 0.0 & 19 \\ 0.0 & 537.8 & 19 \\ 0.0 & 337.9 & 19 \\ 0.0 & 1068.0 & 19 \\ 0.5 & 74459.0 & 42 \\ -1.3 & 372.6 & 19\end{array}$

$\begin{array}{lll}-0.8 & 0.0 & 19\end{array}$

$\begin{array}{lll}-0.9 & 0.0 & 19\end{array}$

$\begin{array}{lll}-1.2 & 0.0 & 19\end{array}$

$\begin{array}{lll}-0.7 & 8581.1 & 19\end{array}$

$\begin{array}{lll}-2.0 & 0.0 & 19\end{array}$

10 of 16 
Table 4 - continued from previous page

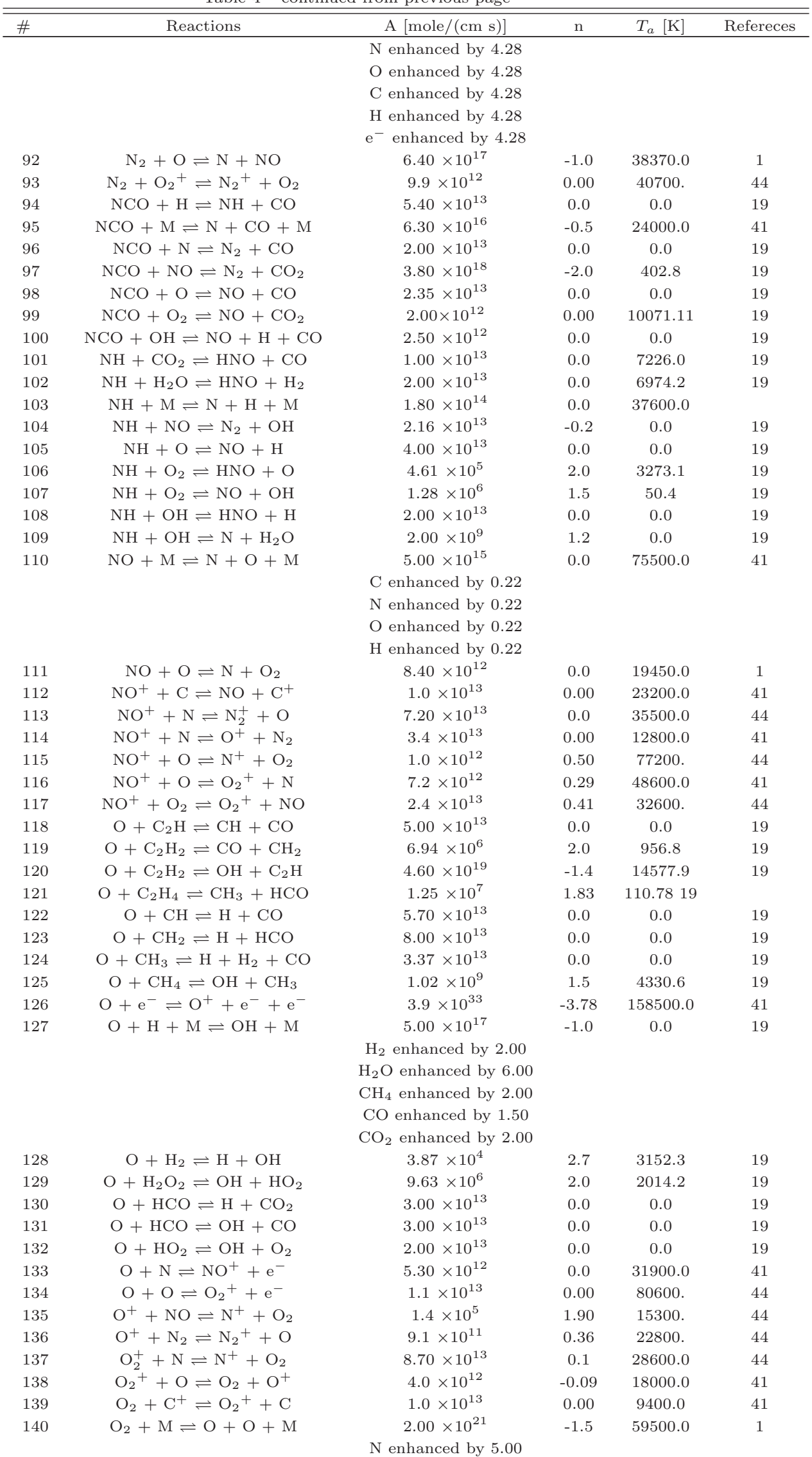

Continued on next page

11 of 16 
Table 4 - continued from previous page

\begin{tabular}{|c|c|c|c|c|c|}
\hline$\#$ & Reactions & $\mathrm{A}[\mathrm{mole} /(\mathrm{cm} \mathrm{s})]$ & $\mathrm{n}$ & $T_{a}[\mathrm{~K}]$ & Refereces \\
\hline & & O enhanced by 5.00 & & & \\
\hline & & $\mathrm{H}$ enhanced by 5.00 & & & \\
\hline & & $\mathrm{C}$ enhanced by 5.00 & & & \\
\hline 141 & $\mathrm{OH}+\mathrm{C} \rightleftharpoons \mathrm{H}+\mathrm{CO}$ & $5.00 \times 10^{13}$ & 0.0 & 0.0 & 19 \\
\hline 142 & $\mathrm{OH}+\mathrm{C}_{2} \mathrm{H}_{2} \rightleftharpoons \mathrm{CH}_{3}+\mathrm{CO}$ & $4.83 \times 10^{-4}$ & 4.0 & -1007.1 & 19 \\
\hline 143 & $\mathrm{OH}+\mathrm{CH} \rightleftharpoons \mathrm{H}+\mathrm{HCO}$ & $3.00 \times 10^{13}$ & 0.0 & 0.0 & 19 \\
\hline 144 & $\mathrm{OH}+\mathrm{CH}_{2} \rightleftharpoons \mathrm{CH}+\mathrm{H}_{2} \mathrm{O}$ & $1.13 \times 10^{7}$ & 2.0 & 1510.7 & 19 \\
\hline 145 & $\mathrm{OH}+\mathrm{CH}_{3} \rightleftharpoons \mathrm{CH}_{2}+\mathrm{H}_{2} \mathrm{O}$ & $5.60 \times 10^{7}$ & 1.6 & 2729.3 & 19 \\
\hline 146 & $\mathrm{OH}+\mathrm{CH}_{4} \rightleftharpoons \mathrm{CH}_{3}+\mathrm{H}_{2} \mathrm{O}$ & $1.37 \times 10^{6}$ & 2.2 & 1350.0 & 45 \\
\hline 147 & $\mathrm{OH}+\mathrm{CO} \rightleftharpoons \mathrm{H}+\mathrm{CO}_{2}$ & $4.76 \times 10^{7}$ & 1.2 & 35.2 & 19 \\
\hline 148 & $\mathrm{OH}+\mathrm{C}_{2} \mathrm{H}_{2} \rightleftharpoons \mathrm{C}_{2} \mathrm{H}+\mathrm{H}_{2} \mathrm{O}$ & $5.60 \times 10^{7}$ & 1.60 & 2729.27 & 19 \\
\hline 149 & $\mathrm{OH}+\mathrm{H}_{2} \rightleftharpoons \mathrm{H}+\mathrm{H}_{2} \mathrm{O}$ & $2.16 \times 10^{8}$ & 1.5 & 1727.2 & 19 \\
\hline 150 & $\mathrm{OH}+\mathrm{H}_{2} \mathrm{O}_{2} \rightleftharpoons \mathrm{HO}_{2}+\mathrm{H}_{2} \mathrm{O}$ & $2.00 \times 10^{12}$ & 0.0 & 215.0 & 19 \\
\hline 151 & $\mathrm{OH}+\mathrm{HCO} \rightleftharpoons \mathrm{H}_{2} \mathrm{O}+\mathrm{CO}$ & $5.00 \times 10^{13}$ & 0.0 & 0.0 & 19 \\
\hline 152 & $\mathrm{OH}+\mathrm{HO}_{2} \rightleftharpoons \mathrm{O}_{2}+\mathrm{H}_{2} \mathrm{O}$ & $1.45 \times 10^{13}$ & 0.0 & -251.8 & 19 \\
\hline
\end{tabular}

\section{B. Comparison}

The reduced model is compared to the complete model in order to assess its validity. First, the experimental results presented earlier are used, as presented in Fig. 5. Even though most of the test-cases presented show differences (10\% at most), the results remain valid and are still in good agreement with the experimental data.

Finally, the two models are compared using the ablating gas composition of trajectory point number 12 of Table 1. As if the gas was traveling through the boundary layer, the initial temperature is set to 5000 $\mathrm{K}$ and the pressure to 0.01 atmosphere. The results are presented in Figs. 6 to 8; in this case, the species concentrations overlap, and no difference is observable for the important species.

\section{Conclusion}

As part of a continuing project to improve heat and ablation rate modeling on hypersonic re-entry vehicles, the first form of a coherent chemistry model for computing the outer flow of a re-entry vehicle using an ablative heat shield has been presented. First, species were chosen in regards to what is deemed important in the flow conditions. Next, reactions were evaluated and chosen from various sources in the literature in order to create a complete model, which was then validated using various experimental results. Next, the model was reduced to a more manageable number of species and reactions, using zero dimensional and one dimensional sensitivity analyses. This reduced model was then compared to the complete model, to insure its validity. Even though this latest model is usable in its present form, the next step will be to further reduce it for improved efficiency in CFD codes.

\section{Acknowledgments}

Financial support for this work was provided in part by the Constellation University Institutes Program, under NASA grant NCC3-989, as well as through NASA Prime Contract NNA04BC25C to ELORET Corporation. The authors would also like to thank Dr. Tahir Gökçen for numerous insightful discussions, as well as to Dr. Thierry Magin and Dr. Guillaume Blanquart for clarifications on chemistry theory. Many thanks are also extended to Dr. Michael Barnhardt, Dr. David Hash and Dr. Christopher Dateo, for managing this project.

\section{References}

\footnotetext{
${ }^{1}$ Park, C., Jaffe, R. L., and Partridge, H., "Chemical-Kinetic Parameters of Hyperbolic Earth Entry," Journal of Thermophysics and Heat Transfer, Vol. 15, No. 1, January- March 2001, pp. 76-90.

${ }^{2}$ Suzuki, K., Kubota, H., Fujita, K., and Abe, T., "Chemical nonequilibrium ablation analysis of MUSES-C super-orbital reentry capsule," 32nd AIAA Thermophysics Conference, No. AIAA-1997-2481, June 23-25 1997.
} 


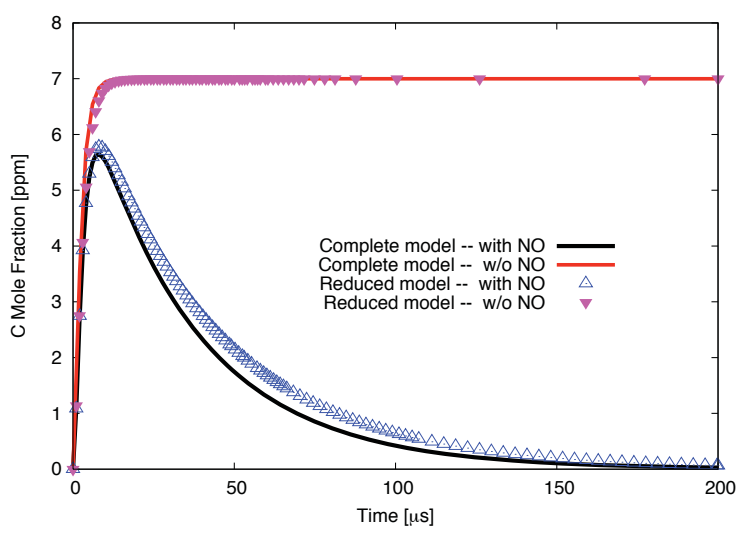

(a) Comparison using a test case from Ref. 27: $T=2864$ $\mathrm{K}, p=1.00$ atm, $7 \mathrm{ppm}$ of $\mathrm{C}_{3} \mathrm{O}_{2}$ and $147 \mathrm{ppm}$ of $\mathrm{NO}$ in Argon

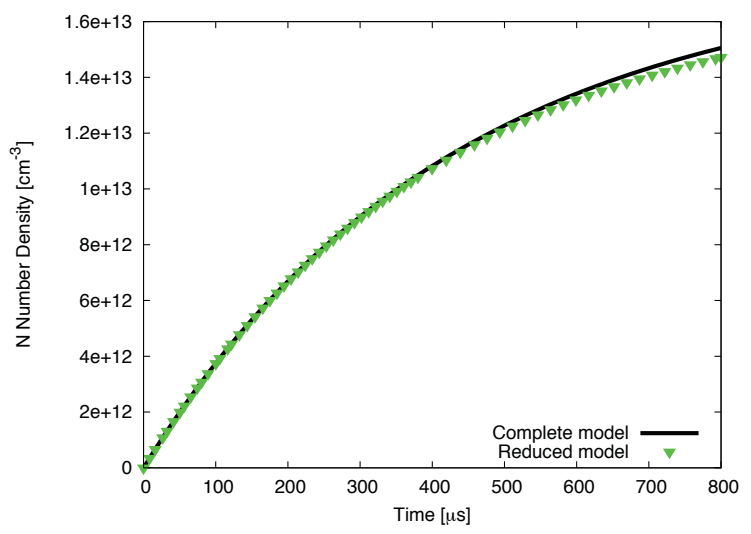

(c) Comparison using a test case from Ref. 28: $T=5290$ $\mathrm{K}, p=1.88$ atm, $5 \mathrm{ppm}$ of $\mathrm{C}_{2} \mathrm{H}_{2}$ in Argon

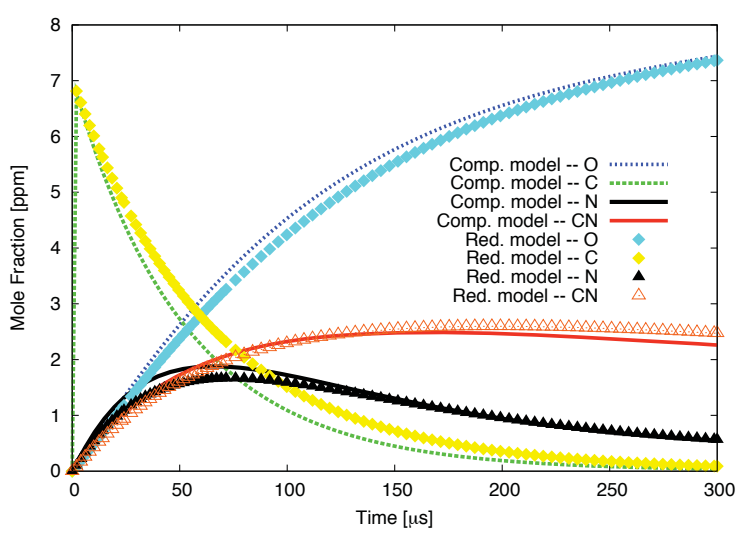

(b) Comparison using a test case from Ref. 27: $T=3620$ $\mathrm{K}, p=0.80 \mathrm{~atm}, 7 \mathrm{ppm}$ of $\mathrm{C}_{3} \mathrm{O}_{2}$ and $147 \mathrm{ppm}$ of $\mathrm{NO}$ in Argon

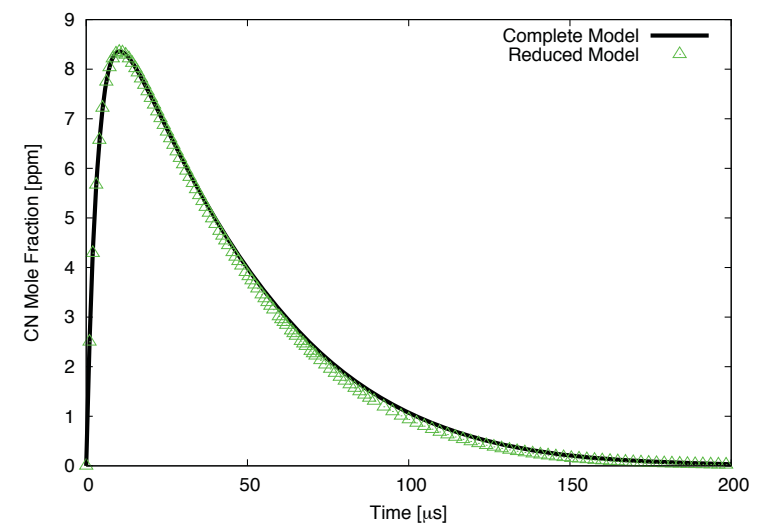

(d) Comparison using a test case from Ref. 23: $T=3470$ $\mathrm{K}, p=0.835 \mathrm{~atm}, 5 \mathrm{ppm}$ of $\mathrm{C}_{2} \mathrm{~N}_{2}$ and $515 \mathrm{ppm}$ of $\mathrm{O}_{2}$ in Argon

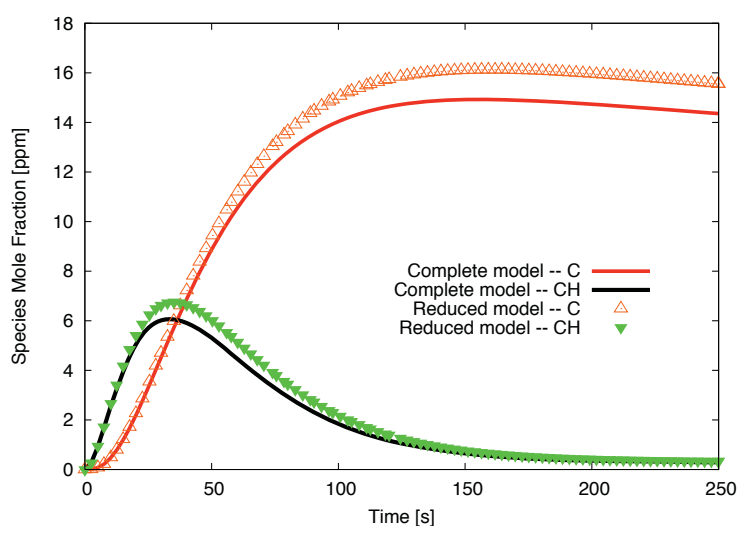

(e) Comparison using a test case from Ref. 29: $T=3100$

$\mathrm{K}, p=0.89 \mathrm{~atm}, 30 \mathrm{ppm}$ of $\mathrm{CH}_{4}$ in Argon

Figure 5. Comparison between the complete and the reduced model 


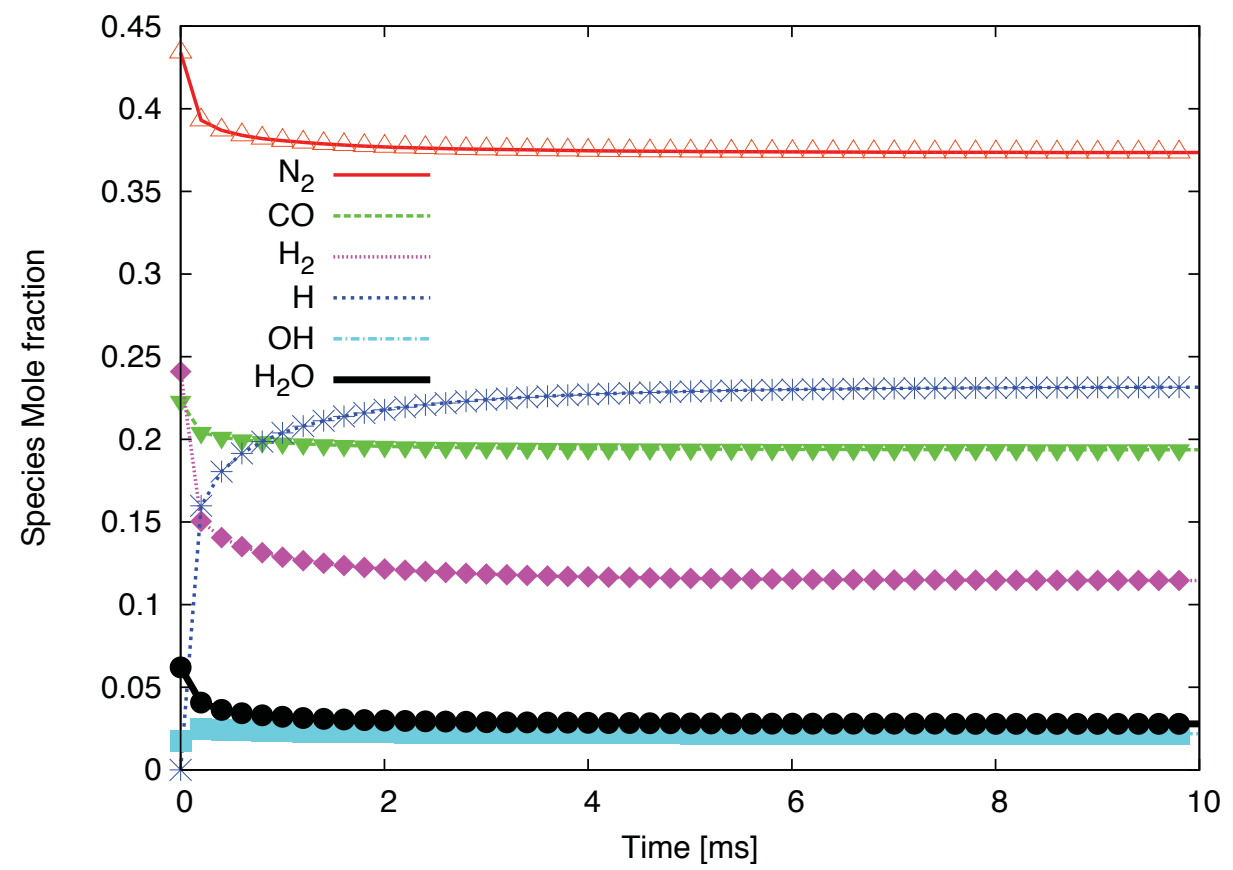

Figure 6. Comparison of the full and reduced model for high concentration species for trajectory point \#12 $(\mathrm{T}=5000 \mathrm{~K}$ and $\mathrm{P}=0.01 \mathrm{~atm})$

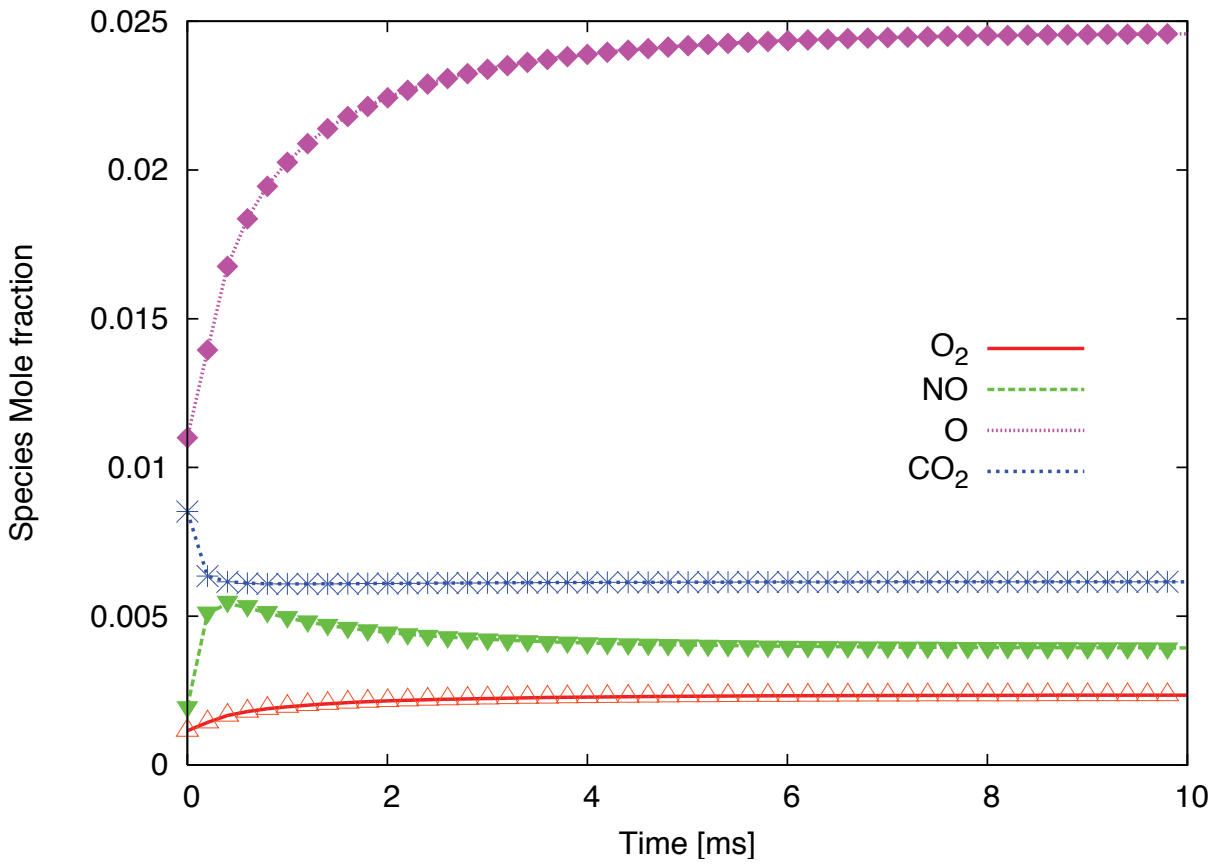

Figure 7. Comparison of the full and reduced model for mid concentration species for trajectory point \#12 ( $\mathrm{T}=5000 \mathrm{~K}$ and $\mathrm{P}=0.01 \mathrm{~atm})$ 


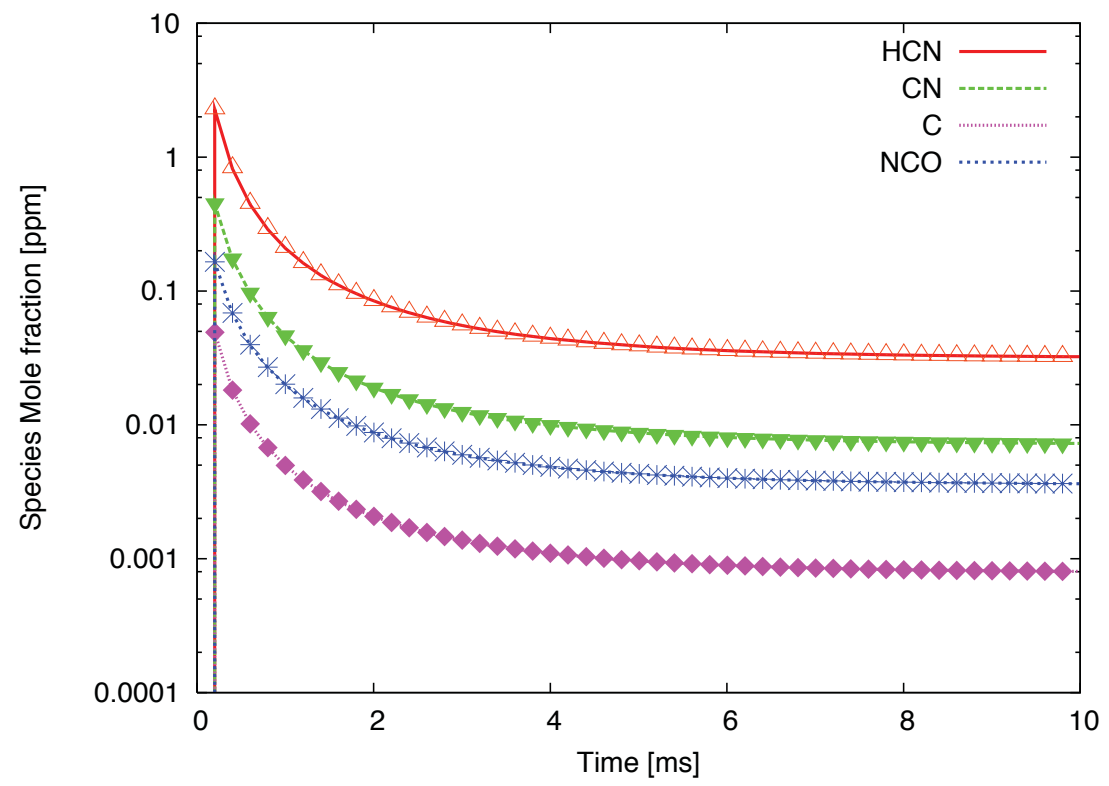

Figure 8. Comparison of the full and reduced model for low concentration species for trajectory point \#12 ( $\mathrm{T}=5000 \mathrm{~K}$ and $\mathrm{P}=0.01 \mathrm{~atm})$

${ }^{3}$ Suzuki, T., Sawada, K., Yamada, T., and Inatani, Y., "Experimental and Numerical Study of Pyrolysis Gas Pressure in Ablating Test Piece," Journal of Thermophysics and Heat Transfer, Vol. 19, No. 3, July-September 2005, pp. $266-272$.

${ }^{4}$ Dec, J. A. and Braun, R. D., "An Approximate Ablative Thermal Protection System Sizing Tool for Entry System Design," 44th AIAA Aerospace Sciences Meeting and Exhibit, No. AIAA 2006-780, Reno, NV, 9-12 January 2006.

${ }^{5}$ Ayasoufi, A., Rahmani, R. K., Cheng, G., Koomullil, R., and Neroorkar, K., "Numerical Simulation of Ablation for Reentry Vehicles," 9th AIAA/ASME Joint Thermophysics and Heat Transfer Conference, No. AIAA 2006-2908, San Francisco, CA, June 5-8 2006.

${ }^{6}$ Amar, A. J., Blackwell, B. F., and Edward, J. R., "One-Dimensional Ablation with Pyrolysis Gas Flow Using a Full Newton's Method and Finite Control Volume Procedure," 39th AIAA Thermophysics Conference, No. AIAA-2007-4535, Miami, FL, 25-28 June 2007, p. 41.

${ }^{7}$ Milos, F. and Chen, Y.-K., "Two-Dimensional Ablation, Thermal Response and Sizing Program for Pyrolyzing Ablators," 46th AIAA Aerospace Sciences Meeting and Exhibit, AIAA-2008-1223, Reno, NV, Jan. 7-10 2008, p. 7.

${ }^{8}$ Venkatachari, B. S., C.Cheng, G., P.Koomullil, R., and Ayasoufi, A., "Computational Tools for Re-entry Aerothermodynamics - Part II. Surface Ablation," 46th AIAA Aerospace Sciences Meeting and Exhibit, AIAA-2008-1218, Reno, NV, Jan. 7-10 2008.

${ }^{9}$ Martin, A. and Boyd, I. D., "Simulation of pyrolysis gas within a thermal protection system," 40th AIAA Thermophysics Conference, No. AIAA-2008-3805, Seattle, WA, June 23-26 2008, p. 20.

${ }^{10}$ Gökçen, T., "N $\mathrm{N}_{2}-\mathrm{CH}_{4}$-Ar Chemical Kinetic Model for Simulations of Titan Atmospheric Entry," Journal of Thermophysics and Heat Transfer, Vol. 21, No. 1, January-March 2007, pp. 9-18.

${ }^{11}$ Scalabrin, L. C. and Boyd, I. D., "Numerical Simulation of Weakly Ionized Hypersonic Flow for Reentry Configurations," 9th AIAA/ASME Joint Thermophysics and Heat Transfer Conference, No. AIAA-2006-3773, San Francisco, CA, June 5-8 2006 , p. 18.

${ }^{12}$ Nompelis, I., Drayna, T. W., and Candler, G. V., "A Parallel Unstructured Implicit Solver for Hypersonic Reacting Flow Simulation," 17th AIAA Computational Fluid Dynamics Conference, No. AIAA 2005-4867, Toronto, ON, 2005.

${ }^{13}$ Wright, M. J., Candler, G. V., and Bose, D., "Data-Parallel Line Relaxation method for the Navier-Stokes equations," AIAA Journal, Vol. 36, No. 9, September 1998, pp. 1603-1609.

${ }^{14}$ Gnoffo, P. A., "Upwind-Biased, Point-implicit Relaxation Strategies for Viscous Hypersonic Flows," 9th AIAA Computational Fluid Dynamics Conference, No. AIAA-1989-1972-CP, Buffalo, NY, June 13-15 1989, pp. 415-425.

${ }^{15}$ Chen, Y.-K. and Milos, F. S., "Ablation and Thermal Response Program for Spacecraft Heatshield Analysis," Journal of Spacecraft and Rockets, Vol. 36, No. 3, May-June 1999, pp. 475-483.

${ }^{16}$ Kinney, D. J., "Aerothermal Anchoring of CBAero using High Fidelity CFD," 45th AIAA Aerospace Sciences Meeting and Exhibit, No. AIAA-2007-0608, Reno, NV, January 8-11 2007.

${ }^{17}$ Milos, F. S. and Chen, Y.-K., "Ablation and Thermal Response Property Model Validation for Phenolic Impregnated Carbon Ablator," 47th AIAA Aerospace Sciences Meeting and Exhibit, No. AIAA 2009-262, Orlando, FL, 5-8 January 2009.

${ }^{18}$ Milos, F. S. and Chen, Y.-K., "Comprehensive model for multicomponent ablation thermochemistry," 35th Aerospace Sciences Meeting and Exhibit, No. AIAA-1997-141, Reno, NV, Jan. 6-9 1997, p. 9.

15 of 16

American Institute of Aeronautics and Astronautics 
${ }^{19}$ Smith, G. P., Golden, D. M., Frenklach, M., Moriarty, N. W., Eiteneer, B., Goldenberg, M., Bowman, C. T., Hanson, R. K., Song, S., William C. Gardiner, J., Lissianski, V. V., and Qin, Z., "GRI-Mech 3.0," 2009.

${ }^{20}$ Louge, M. Y. and Hanson, R. K., "Shock Tube Study of Cyanogen Oxidation Kinetics," International Journal of Chemical Kinetics, Vol. 16, No. 3, 1984, pp. 231-250.

${ }^{21}$ Mozzhukin, E. V., Burmeister, M., and Roth, P., "High Temperature Dissociation of CN Radicals," Ber. Bunsenges. Phys. Chem., Vol. 93, 1989, pp. 70-75.

${ }^{22}$ Lindackers, D., Burmeister, M., and Roth, P., "High-Temperature Kinetics of the Reaction $\mathrm{CN}^{+} \mathrm{CO}_{2}$,"Combustion and Flame, Vol. 81, No. 3-4, 1990, pp. 251-259.

${ }^{23}$ Davidson, D. F., Dean, A. J., Dirosa, M. D., and Hanson, R. K., "Shock tube measurements of the reactions of CN with O and O2," International Journal of Chemical Kinetics, Vol. 23, No. 11, 1991, pp. 1035-1050.

${ }^{24}$ Baulch, D. L., Cobos, C. J., Cox, R. A., Esser, C., Frank, P., Just, T., Kerr, J. A., Pilling, M. J., Troe, J., Walker, R. W., and Warnatz, J., "Evaluated Kinetic Data for Combustion Modelling," Journal of Physical and Chemical Reference Data, Vol. 21, No. 3, 1992, pp. 411-734.

${ }^{25}$ Andersson, S., Markovic, N., and Nyman, G., "Computational Studies of the Kinetics of the C $+\mathrm{NO}$ and $\mathrm{O}+\mathrm{CN}$ Reactions," J. Phys. Chem. A, Vol. 107, 2003, pp. 5439-5447.

${ }^{26}$ Kee, R. J., Rupley, F. M., Miller, J. A., Coltrin, M. E., Grcar, J. F., Meeks, E., Moffat, H. K., Lutz, A. E., Dixon-Lewis, G., Smooke, M. D., Warnatz, J., Evans, G. H., Larson, R. S., Mitchell, R. E., Petzold, L. R., Reynolds, W. C., Caracotsios, M., Stewart, W. E., Glarborg, P., Wang, C., McLellan, C. L., Adigun, O., Houf, W., Chou, C. P., Miller, S. F., Ho, P., Young, P. D., Young, D. J., Hodgson, D. W., Petrova, M. V., and Puduppakkam, K. V., "CHEMKIN, Release 4.1," 2006.

${ }^{27}$ Dean, A. J., Hanson, R. K., and Bowman, C. T., "A Shock Tube Study of Reactions of C Atoms and CH with NO Including Product Channel Measurements," Journal of Chemical Physics, Vol. 95, 1991, pp. 3180-3189.

${ }^{28}$ Mick, H.-J. and Roth, P., "High Temperature Thermal Decomposition of CO and CN," Shock Waves, edited by SpringerVerlag, Berlin, 1992, p. 805.

${ }^{29}$ Dean, A. J. and Hanson, R. K., "CH and C-atom time histories in dilute hydrocarbon pyrolysis: Measurements and kinetics calculations," International Journal of Chemical Kinetics, Vol. 24, No. 6, 2004, pp. 517 - 532.

${ }^{30}$ Tran, H. K., Johnson, C. E., Rasky, D. J., Hui, F., Hsu, M., Chen, T., Chen, Y., Paragas, D., and L.Kobayashi, "Phenolic Impregnated Carbon Ablators (PICA) as Thermal Protection Systems for Discovery Missions," Tech. Rep. TM-110440, NASA, 1997.

${ }^{31}$ Dean, A. J., Davidson, D. F., and Hanson, R. K., "A Shock Tube Study of Reactions of C Atoms with $\mathrm{H}_{2}$ and $\mathrm{O}_{2}$ Using Excimer Photolysis of $\mathrm{C}_{3} \mathrm{O}_{2}$ and $\mathrm{C}$ Atom Atomic Resonance Absorption Spectroscopy," The Journal of Physical Chemistry, Vol. 95, No. 1, 1991, pp. 183-191.

${ }^{32}$ Baulch, D. L., Cobos, C. J., Cox, R. A., Frank, P., Hayman, G., Just, T., Kerr, J. A., Murrells, T., Pilling, M. J., Troe, J., Walker, R. W., and Warnatz, J., "Evaluated Kinetic Data for Combustion Modeling. Supplement I," Journal of Physical and Chemical Reference Data, Vol. 23, No. 6, 1994, pp. 847-848.

${ }^{33}$ Kruse, T. and Roth, P., "Kinetics of $\mathrm{C}_{2}$ Reactions During High-Temperature Pyrolysis of Acetylene," Journal of Physical Chemistry A, Vol. 101, No. 11, 1997, pp. 2138-2146.

${ }^{34}$ Sommer, T., Kruse, T., and Roth, P., "Perturbation Study on the Reaction of $\mathrm{C}_{2}$ with $\mathrm{N}_{2}$ in High-Temperature $\mathrm{C}_{6} 0 / \mathrm{Ar}$ $+\mathrm{N}_{2}$ Mixtures," Journal of Physical Chemistry A, Vol. 101, No. 20, 1997, pp. 3720- 3725.

${ }^{35}$ Dean, A. J. and Hanson, R. K., "CH and C-Atom Time Histories in Dilute Hydrocarbon Pyrolysis: Measurements and Kinetic Calculations," International Journal of Chemical Kinetics, Vol. 24, No. 6, 1992, pp. 517-532.

${ }^{36}$ Dean, A. J., Hanson, R. K., and Bowman, C. T., "High Temperature Shock Tube Study of Reactions of CH and CAtoms with $\mathrm{N}_{2}$," Twenty- Third Symposium (International) on Combustion, edited by T. C. Institute, Pittsburgh, PA, 1990, pp. 259-265.

${ }^{37}$ Bauerle, S., Klatt, M., and Wagner, H. G., "Recombination and decomposition of methylene radicals at high temperatures," Ber. Bunsenges. Phys. Chem., Vol. 99, 1995, pp. $870-879$.

${ }^{38}$ Bohland, T., Dobe, S., Temps, F., and Wagner, H., "Kinetics of the reactions between $\mathrm{CH}_{2}\left(\mathrm{X}^{3} \mathrm{~B}_{1}\right)$-radicals and saturated hydrocarbons in the temperature range $296 \mathrm{~K}-707 \mathrm{~K}, "$ Ber. Bunsenges. Phys. Chem., Vol. 89, 1985.

${ }^{39}$ Sanders, W., Lin, C., and Lin, M., "Short communication on the importance of the reaction $\mathrm{CH}_{2}+\mathrm{N}_{2}=\mathrm{HCN}+\mathrm{NH}$ as a precursor for prompt NO formation," Combust. Sci. Technol., Vol. 51, 1987, pp. $103-108$.

${ }^{40}$ Tsang, W. and Hampson, R., "Chemical kinetic data base for combustion chemistry. Part I. Methane and related compounds," J. Phys. Chem. Ref. Data, Vol. 15, 1986.

${ }^{41}$ Park, C., Howe, J. T., Jaffe, R. L., and Candler, G. V., "Review of Chemical Kinetic Problems of Future NASA Missions, II: Mars Entries," Journal of Thermophysics and Heat Transfer, Vol. 8, No. 1, March 1994, pp. 9-23.

${ }^{42}$ Caridade, P., Rodrigues, S., Sousa, F., and Varandas, A., "Unimolecular and bimolecular calculations for HN 2 ," J. Phys. Chem. A, Vol. 109, 2005, pp. $2356-2363$.

${ }^{43}$ Tsang, W. and Herron, J. T., "Chemical Kinetic Data Base for Propellant Combustion 1. Reactions Involving NO, NO2 , HNO, HNO2, HCN and N2O," Journal of Physical Chemistry Reference Data, Vol. 20, No. 4, 1991, pp. 609-663.

${ }^{44}$ Park, C., Nonequilibrium Hypersonic Aerothermodynamics, Wiley-Interscience, February 1990.

${ }^{45}$ Baulch, D. L., Bowman, C. T., Cobos, C. J., Cox, R. A., Just, T., Kerr, J. A., Pilling, M. J., Stocker, D., Troe, J., Tsang, W., Walker, R. W., and Warnatz, J., "Evaluated Kinetic Data for Combustion Modeling: Supplement II," Journal of Physical and Chemical Reference Data, Vol. 34, No. 3, 2005, pp. 757-1397. 